


\title{
Afet Yönetişiminde Sivil Toplum ve Güven Algıları*
}

\author{
Civil Society and Perceptions of Trust in Disaster Governance
}

\section{Fahri Çak1}

Öz

Türkiye'de mevcut literatür, "güçlü ve ceberut devlet geleneği" ile "zayıf sivil toplum" ilişkisinden kaynaklanan "merkeziyetçi ve başarısız afet yönetimi pratiklerinin" afetlere karşı güvenlik açıkları yarattı̆̆ını ileri sürer ve çözüm olarak, afet yönetişimi kavramı çerçevesinde, devlet ve sivil toplum kuruluşlarının afet riskini azaltmak için sorumlulukları paylaşmalarını önerir. Literatür aynı zamanda 1999 Marmara depremleri sırasında ve sonrasında oynadıkları pozitif rollerle STK'ların toplumsal tabanda büyük bir güven kazanmasına karşın merkezi devletin güven kaybına uğradığı görüşünde birleşmektedir. Bu makale, afet yönetişiminde aktif rol almaları beklenen aktörler arasındaki güven algılarının güncel durumunu incelemeyi, bu suretle "güçlü devlet" ve "zayıf sivil toplum" kavramları çerçevesindeki kuramsal önermelerin doğruluğunu güncel görgül verilerle sınamayı ve 2020 yılı itibariyle Türkiye'de afet yönetişimi aktörlerinin birbirlerine güven ve işbirliği hususunda fiili durumun ne olduğunu incelemeyi amaçlamaktadır. Makale, afet yönetişiminin Türkiye' deki özel durumunu, Balıkesir örnek olayı çerçevesinde nicel ve nitel yöntemleri birlikte kullanarak incelemektedir. Ana bulgular, sivil topluma güvenin devlet kurumlarına güvenin gerisinde olduğu, AFAD'ın yönetişim ilkelerine daha açık olmasına karşın toplumsal tabanın güvenini en çok belediyelerin kazandığıdır. Makale, yerel yönetimlerin ve merkezi devlet kurumlarının kendini kanıtlamış, siyaset üstü STK'larla daha fazla iletişim ve işbirliği geliştirmesi, afet yönetimine katkı sunmak isteyen STK'ların da güven tazelemesi gerekli sonucuna ulaşmaktadır.

Anahtar Kavramlar: Doğal afet, afet yönetişimi, sivil toplum, yerel yönetimler, merkezi devlet, güven algıları

Bu makalenin veri kaynağı olan ve 2017-2019 yılları arasında yürütülen 116K208 Numaralı “Balıkesir'de Aile, Yerel Yönetimler ve Doğal Afetler: Farkındalık, Hazırlık, Güven ve Sosyal Sermaye Açılarından Sosyolojik Bir İnceleme" başlıklı proje, TÜBİTAK (1001) tarafından desteklenmiştir.

** Prof. Dr. Balıkesir Üniversitesi, Fen-Edebiyat Fakültesi, Sosyoloji Bölümü öğretim üyesi, cakifahri@balikesir.edu.tr

Bu makale iThenticate sistemi tarafından taranmıştır.

Makale Gönderim Tarihi: 15 Nisan 2020 


\begin{abstract}
The literature on disasters in Turkey argues that "centralized and unsuccessful disaster management practices" stemming from the relationship of "despot and strong state tradition" and "weak civil society" create security gaps against disasters. As a solution, the literature proposes the concept of disaster governance by which the state and non-governmental organizations share responsibilities to reduce disaster risks. The literature also concludes that, with their positive roles during and after the 1999 Marmara earthquakes, CSOs have gained a great deal of trust from the social base while the central government has lost the trust of its citizens. This article examines the current state of perceptions of trust among the actors who are expected to take active roles in disaster governance; in this way, it aims to test, with recent empirical data, the accuracy of theoretical propositions based on the concepts of "strong state" and "weak civil society". The article, thus, aims to explore what the actual situation is in terms of trust and cooperation among the actors of disaster governance in Turkey in 2020.

Based on a case study of Balikesir using qualitative and quantitative methods together, the article examines the special situation of disaster governance in Turkey. The main findings are that trust in civil society lags behind trust in state institutions and that municipalities gain the trust of local communities the most although AFAD appears to be more open to governance principles. The article concludes that local and central government agencies should develop more communication and cooperation with NGOs who have proven themselves to be supra-political in nature while those NGOs who want to contribute to disaster management should reassure their trustworthiness.
\end{abstract}

Keywords: natural disaster, disaster governance, civil society, local governments, the state, perceptions of trust. 


\section{Giriş}

Merkeziyetçi devlet, Türk sosyolojisinin en eski problematiklerinden birisidir. Prens Sabahattin'den beri birçok Türk aydını devletin merkeziyetçi karakterini, "baba” figürünü, geri kalmışlık sorunuyla birlikte başka birçok sorunun ana kaynağı olarak görmüştür. Türkiye üzerine odaklanan yabancı araştırmacılar da genellikle aynı eğilimi gösterirler. Türkiye'nin afet (özellikle deprem) gerçeği karşısında da başarısız bir performans sergilediğini kabul eden söz konusu yaklaşımlar, sivil toplumun gelişmesine izin vermeyen "güçlü devlet" geleneğini bu sonucu doğuran ana neden olarak görme eğilimdedirler.

Türkiye'nin sorunlarının çözümü adem-i merkeziyetçiliğe geçişle ilişkilendirilir. Adem-i merkeziyetçilik, "otoritenin daha küçük sayıda aktörlerden daha büyük sayıda aktörlere yayılmasını ve merkezi bir otoriteden daha az merkezi bir otoriteye geçişi" içerir (Pollitt, 2005: 373). Ademi merkeziyetçilik, ulusal hükümetin tek başına mevzuatın gerektirdiği tüm işlev ve yetkileri yerine getiremediği ana fikrine dayanır (Ile, 2009). Bu fikir afet yönetimine uyarlandığında "afetlerle ilişkili etkileri ve kayıpları azaltmak için tasarlanmış birbiriyle ilişkili normlar, örgütsel ve kurumsal aktörler ve uygulamalar (afet öncesi, sırası ve sonrası aşamalarda) dizisi" şeklinde tanımlanan (Tierney, 2021: 344) bir afet yönetişimi kavramı üretilmiş olur. Doğası çok aktörlülüğü içeren afet yönetişimi, bireyler, hane halkları, topluluklar, hükümetler, özel sektörler, akademi, sivil toplum, askeri kuruluşlar, ikili bağışçılar, çok taraflı kuruluşlar, Kızılhaç/Kızılay vb. güç odakları ve sosyal aktörlerin afet riskini azaltmak için sorumlulukları paylaşmaları anlamina gelir (Sandoval \& Voss, 2016: 108).

Afet yönetişiminde sayılan bu aktörler arasında özel bir önem verilen sivil toplum, sivil toplum kuruluşları (STK'lar), gönüllüler ve dini örgütler, devlet-dışı bireyler, düşünce kuruluşları, sosyal hareket özneleri, üniversite tabanlı uzmanlar veya akademisyenler, savunma grupları ve diğer taban toplulukları gibi aktörleri içerir (Özerdem ve Jacoby, 2006: 15) ve yönetimde şeffaflık sağlamak, hükümete yapıcı alternatif politikalar sunmak (Osa, 2013: 71), yerel afet planlaması ve dirençlik inşasına kapsamlı ve uzlaş- 
macı yaklaşımlar sunmak, yerel toplulukların gerçek ihtiyaçları ve önceliklerini ifade etmelerini mümkün kılmak (Maskrey, 1989: 84; Lassa, 2018) gibi avantajlarından ve faydalarından söz edilir.

Afet yönetiminde sivil toplum ile devlet kurumları arasındaki ilişki ve işbirliğinin gücünü ve kapsamını belirleyen faktörlerden muhtemelen en önemlisi, devlet-sivil toplum arasındaki güvene bağlıdır. Nitekim güven temelli ilişkiler, afet de dahil olmak üzere, etkili acil durum müdahaleleri için kritik öneme sahip görülür (Janssen vd., 2010; Kapucu ve Garayev, 2011; Longstaff ve Yang, 2008).

Türkiye'de afet yönetimi ve devlet-sivil toplum ilişkisi üzerine bina edilmiş olan literatür, afet yönetiminin başat aktörünün Türkiye'de devlet olduğunu, sivil toplumun bu süreçte aktif rol alabilmesi için gerekli koşulların sağlanmadığı görüşündedir (Tarih Vakf1, 2000; Kubicek, 2002; Ganapati; 2005; Özerdem ve Jacoby, 2006). Bu literatür "güçlü ve ceberut devlet geleneği" ile "zayıf sivil toplum" ilişkisinden kaynaklanan "merkeziyetçi ve başarısız afet yönetimi pratiklerinin" afetlere karşı güvenlik açıları yarattığını ileri sürer (Aydıner ve Özgür, 2014: 400).

Söz konusu literatür aynı zamanda 1999 Marmara depremlerinden sonra STK'ların depremlerdeki aktif ve pozitif rolleriyle toplumsal tabanda büyük bir güven kazanmasına karşın merkezi devletin güven kaybına uğradığ1 görüşünde de birleşmektedir. Yerel yönetimlerin merkezi devlete ve sivil topluma ne düzeyde güvendikleri ve onlarla ne kadar işbirliği içinde oldukları ise nispeten muğlak bir alandır. Ayrıca bu literatür 'güçlü devlet' anlayışının "zayıf sivil toplum" sonucunu ürettiğini, bunun da etkisiz ve verimsiz bir afet yönetimine yol açtığını bazen açık bazen de örtük bir şekilde savunmaktadırlar. Ne var ki son 20 yılda Türkiye'nin toplumsal ve siyasal yaşamında meydana gelen önemli olaylar bu savların birçoğunu, özellikle toplumsal tabanın (hanehalklarının) ve yerel yönetimlerin sivil topluma güveniyle ilgili olanlarını, görgül verilerle sınanmayı gerekli kılmaktadır. 1999 Marmara depremleri sonrasında basında bir süre yer alan sivil topluma ilgi ve güven belirtilerinin hala toplumsal tabanda 
devam ettiği düşüncesinin bir varsayım mı yoksa bir gerçeklik mi olduğu sorgulanmayı gerektirmektedir.

Bu makale afet yönetişiminde aktif rol almaları beklenen aktörler arasındaki güven algılarının güncel durumunu incelemeyi ve bu suretle "güçlü devlet" ve "zayıf sivil toplum" kavramları çerçevesindeki kuramsal önermelerin doğruluğunu görgül verilerle sınamayı amaçlamaktadır. Bu amaçlar doğrultusunda makalenin odaklandığ1 ana araştırma sorusu, 2020 yılı itibariyle Türkiye'de afet yönetişimi aktörlerinin birbirlerine güven ve işbirliği hususunda fiili durumun ne olduğudur. Spesifik olarak toplumsal tabanın ve yerel yönetimlerin devlet kurumlarına ve sivil topluma güven durumları nasıldır? Makale, doğal afet yönetişiminin Türkiye'deki özel durumunu, birçok doğal afet riskinin yoğun hissedildiği illerden biri olan Balıkesir örnek olayı çerçevesinde incelemeyi amaçlamaktadır.

\section{Kavramsal Çerçeve}

\section{Afet (Risk) Yönetişimi}

Son yıllarda risk azaltma için potansiyel bir yol olarak ortaya çıan afet yönetişimi (Ammann vd., 2006) Hyogo Eylem Çerçevesi`nin (HFA) beş temel öncelik alanında da yer almaktadır (UNISDR 2005). Afet yönetişimi ile afet döngüsü (afete müdahale, kurtarma, yeniden yapılanma, azaltım ve hazırbulunuşluk) içindeki doğal veya insan yapımı tehlikeleri tahmin etmek, onlarla başa çıkmak, onlara direnmek ve onlardan iyileşmek için çoklu sosyal ve coğrafi ölçeklerde organize edilen birbiriyle ilişkili düzenleyici çerçeveler ve normlar, kuruluşlar, kurumlar ve uygulamalar seti kastedilir (Gall vd., 2014). Benzer şekilde Tierney'e (2012: 344) göre de afet yönetişimi, "doğal ve teknolojik ajanlardan ve kasıtlı terör eylemlerinden kaynaklanan afetlerle ilişkili etkileri ve kayıpları azaltmak için tasarlanmış birbiriyle ilişkili normlar, örgütsel ve kurumsal aktörler ve uygulamalar (afet öncesi, sırası ve sonrası aşamalarda) dizisinden oluşur." Buna göre afet yönetişimi, a) yerelden küresele olmak üzere tüm ölçeklerde faaliyet gösteren, b) tüm paydaşların (ör. devlet, özel işletmeler, sivil toplum kuruluşları, akademi) katılımıyla, c) kolektif eylemleri teşvik eder. Nihai 
amacı itibariyle afet yönetişimine, "afet risk yönetişimi" demek de mümkündür (Gall vd., 2014:6).

Afet risk yönetişimi yaklaşımının ardalanında afeti kimin/neyin eylemi olarak görüldüğü yatar. Bu yaklaşım afeti Tanrı'nın ya da doğanın bir eylemi olarak görmez. Basit bir şekilde bu yaklaşım 2010 'da Haiti'de ya da 2011'de Japonya'da olduğu gibi korkunç afetler yaşanmasını "ne tamamen doğadan ne de sosyal olana dışsal herhangi bir şeyle ilgili değil, tamamen toplumsal veya kültürel başarısızlıkla ilgili" bir sonuç olarak görür. Dolayısıyla bu yaklaşımın temel önkabullerine göre afetin yol açtığı yıkım ve kayıpların suçlusu "öncelikle (kötü) yönetişimdir" (Sandoval ve Voss, 2016: 108; Alexander, 2005). Diğer bir deyişle doğa olaylarının (risk ve tehlikelerin) afete dönüşmesi insan eylemlerinin ürünü olarak kabul edildiği için yine insan eylemleri sayesinde afet risklerinin azaltılabileceği düşünülür. Bu yaklaşım olası olumsuz etkiler ve afet kayıplarının daha ziyade insanların ve sosyo-ekolojik sistemlerin güvenlik açığına maruz kalmaları ve kırılganlıkları ile belirlendiğini savunur (Voss, 2008). Dolayısıyla afet risk yönetişimi paradigmasında toplulukların kırılganlıklarının azaltılması ve dirençliliklerinin arttırılması temel hedefler olarak belirir. Her ikisi de sosyal/politik araçlarla üretilen bir sonuçtur (Wisner vd., 2004). Bu bağlamda toplumlararası eşitsizliklerin afet kırılganlığına etkisi üzerine (örn. Peduzzi vd. 2009, Kahn, 2005, Raschky, 2008) ve toplum-içi eşitsizliklerin afet kırılganlığına etkisi üzerine de yapılmış bir araştırmalar kütlesi mevcuttur. Bu tür araştırmalar yoksulların, göçmenlerin, çocukların, engellilerin (Stough, 2010), yaşlıların (Hartog, 2014 Bayraktar ve Dalyılmaz, 2018; Bodstein ve Barros, 2014), özel bakıma muhtaçların (Nick vd., 2009) ve kadınların (Pincha, 2008, Enarson, 2012, Odabaş, 2010) diğer toplumsal kesimlere kıyasla afetler karşısında nasıl daha fazla kırılgan olduklarını ve çok daha fazla etkilendiklerini göstermeye çalışırlar.

Afet riskini azalmanın en temel yolu toplulukların direncini yükseltmek, diğer bir deyişle afete dirençli topluluklar oluşturmaktır. Birçok farklı tanımı olmakla birlikte dirençlilik, "fiili veya potansiyel olumsuz olaylara hazırlanma, planlama yapma, sindirme, bunlardan kurtulma veya daha başarılı bir şekilde adapte olma 
yeteneği" olarak tanımlanabilir (NRC, 2012'den aktaran Gall vd., 2014:8). Bu yeteneğin gerçekten sağlanabilmesi aslında yoksulluk, ekonomik güvensizlik, gıda güvensizliği ve hızlı kentleşme gibi afet riskinin altında yatan ana nedenleri çözmeye çalışır. Bu nedenle afet riskini azaltma, bir anlamda kırılganlıkları azalmayla eşanlamlıdır ve kalkınma çalışmalarıyla yakından bağlantılıdır. Afet riskini azalma, sürdürülebilir olmayan kalkınma modellerinin insanların tehlikelerle başa çıkma kapasitesini azalttığı ve böylece afetlere neden olduğu öncülüne dayanmaktadır (Give2Asia \& IIRR, 2017:8). Bu öncülün mantığı çerçevesinde toplulukların direncini yükseltme hedefi, toplulukların sürece dâhil edilmesini yani topluluk temelli afet yönetişimini gerekli kılar. Geleneksel olarak yukarıdan aşağıya afet yönetimi ortamlarında toplulukların genellikle afet riskinin azaltılması için karar verme sürecinden dışlandıkları ve görüşlerinin ve ihtiyaçlarının genellikle dikkate alınmadığı görülür. Ancak topluluk temelli afet yönetişimiyle, toplulukların seslerini duyurabilmeleri ve ihtiyaçlarının fark edilebilmesi için uygun olanakların doğduğu kabul edilir. Dolayısıyla topluluk temelli afet yönetişimi, katılımcı yönetişim yoluyla dirençli topluluklar oluşturulmasının gerekliliğine ve olasılığına inanmayı ifade eder.

Yönetişim kavramının çok aktörlülüğü içermesi dikkate alındığında afet risk yönetişiminin, toplumda mevcut bireyler, hane halkları, topluluklar, hükümetler, özel sektörler, akademi, sivil toplum, askeri kuruluşlar, ikili bağışçllar, çok taraflı kuruluşlar, Kızılhaç/ Kızılay vb. güç odakları ve sosyal aktörler setini içerdiği söylenebilir (Sandoval ve Voss, 2016: 108). Afet riski yönetişimi kavramı, söz konusu bu aktörlerin afet riskini azaltmak için sorumlulukları paylaşmaları anlamına gelir. Bütün bu aktörler arasındaki ilişkiler yatay ve dikey yönetişim düzenlemelerinde yapılandırılabilir (Renn, 2008).

Birleşmiş Milletler de dâhil birçok ulusal ve uluslararası aktör afet risk yönetişimine büyük önem vermelerine rağmen 2011 Küresel Değerlendirme Raporu (UNISDR, 2011: 116), “mevcut risk yönetişim kapasiteleri ve düzenlemelerinin genellikle amaçlarını gerçekleştiremediği" sonucuna varmıştır. Bu sonuç afet risk yö- 
netişiminin uygulamada çeşitli sorunlarla karşı karşıya olduğunu göstermektedir. Nitekim Birleşmiş Milletler bir başka yayınında, daha spesifik olarak, "pek çok ülke tarafından benimsenen ve ağırlıklı olarak uzmanlaşmış acil durum yönetim organizasyonlarına dayanan yönetişim düzenlemeleri, afet riskini ele almak için her zaman uygun değildir" değerlendirmesini yapmakta ve "afet yönetimi döngüsüne dayanan ve özel bir afet riski yönetim sektörü ile temsil edilen yönetişim yaklaşımı sınırına ulaşmış olabilir" tespitiyle bu sorunların ciddiyetine dikkat çekmektedir (UNISDR, 2015: 128).

Bu sorunlarla ilgili olarak Sandoval ve Voss (2016) afet yönetişiminde her toplumun kendine özgü sosyokültürel, tarihi koşullarını esas alması gerektiğine dikkat çekerler. Çünkü, onlara göre, "afet yönetişimi için 'herkese uyan' bir yaklaşım yoktur. Bunun yerine, afetlerin meydana gelişini azaltmak veya kaçınılmazsalar, en azından etkilerini azaltmak için yönetişim uygulamalarını tarihselleştirmeye ve bağlamsallaştırmaya ihtiyaç vardır" (Sandoval ve Voss, 2016: 114). Bu görüşlere paralel olarak afetlerle ilgili iyi yönetişimin yerel bağlama, kültürel ve tarihsel koşullara bağlı olduğu sıklıkla savunulur (Krieger 2013; Dahiya 2012).

Genel olarak afet risk yönetişiminin en önemli aktörlerinden birisi kabul edilen sivil toplumun yönetişim sürecindeki rolleri sözü edilen sorunlarla yakından ilişkilidir. Nitekim "güçlü sivil toplumun" yönetişim kalitesinde en belirleyici faktör olduğu sıklıkla ileri sürülür (Pelling, 2011). Bu nedenle bir sonraki başlık sivil toplum-afet yönetişimi ilişkisine odaklanacaktır.

\section{Afet (Risk) Yönetişiminde Sivil Toplumun Yeri}

Sivil toplum kavramı Aristo'nun "politik topluluk" kavramına kadar geriye giden uzun bir geçmişi olmasına rağmen en büyük etki gücünü 20. Yüzyılda aldığı söylenebilir. Nitekim kapitalizmin ve büyük ölçekli siyasi merkezileşmenin etkisi altında, genel olarak sivilliğin devlete karşı konumlanan bir önem kazandığı gözlenir (Özerdem ve Jacoby, 2006: 13). Edwards'ın (2004: 7) belirttiği gibi, sivil toplum, örgütlü gönüllü dernekler aracılı̆̆ıyla yeni gerçekleştirilen bireysel hak ve özgürlüklere yönelik devletin müda- 
halelerine ve haksızlığa karşı bir savunma olarak görüldü (aktaran Özerdem ve Jacoby, 2006: 13). Bununla beraber sivil toplum devletle bir karşıtlık ilişkisi içinde olmak zorunda değildir. Sivil toplum devletle işbirliği yapan ve onu tamamlayan bir konumda da olabilir.

Sivil toplum aktörleri, sivil toplum kuruluşları (STK'lar), gönüllüler ve dini örgütler, devlet-dışı bireyler, düşünce kuruluşları, sosyal hareket özneleri, üniversite tabanlı uzmanlar veya akademisyenler, savunma grupları ve diğer taban toplulukları gibi geniş bir yelpazeden oluşur (Özerdem ve Jacoby, 2006: 15). Birleşmiş Milletler, sivil toplum örgütlerinin (STÖ’ler) ağırlıklı olarak STK'lara eşit olduğunu düşünür. Sivil toplum, "devlet ve kâr amaçlı firmaların yanında mevcut ve onlarla etkileşime giren üçüncü bir sektörü oluşturmaktadır" (UNDP, 2001). Böyle bir görüş STK / STÖ kavramlarını devlet ve pazar "arasında" birlikte var olan varlıklar olarak desteklemektedir (Lassa, 2018: 3).

Sivil toplum aktörleri birçok farklı alanda etkinlik gösterebilirler. Kuşkusuz bu alanların içinde en önemlilerden birisi afet yönetimidir. Literatür, afet yönetişiminde sivil toplumun niçin etkin rol oynaması gerektiğine ilişkin çok zengin bir veri ve düşünce seti sunar (Jalali, 2002; Sharma ve Palakudiyil, 2003; Shaw ve Goda, 2004; Osa, 2013; Lassa, 2018). Her şeyden önce bu, yönetişim ve demokratikleşme ilkelerinin bir gereği olarak savunulur. Bu bağlamda sivil toplum kuruluşlarının yönetimde şeffaflık sağlayacağ1 ve hükümete yapıcı alternatif politikalar sunabileceği ileri sürülür (Osa, 2013: 71). Bunun yanı sıra afet yönetiminde sivil toplumun çeşitli avantajlarından ve faydalarından söz edilir. Örneğin, hükümetlerin ve işletmelerin aksine, STK'ların, farklı kırılgan ve ötekileştirilmiş gruplar ile (cinsiyet grupları, çocuklar ve yaşlanan nüfus vb.) yakın bir ilişkisinin bulunduğu ve bu gruplarla ilgili güvenlik açı̆̆ının azaltılmasında STK'ların karar alma süreçlerine dahil edilmesinin afet yönetiminde yeni sınırlar açan benzersiz vizyon ve esneklik sağlayacağı savunulur. Buna göre STK'lar, genellikle yerel afet planlaması ve dirençlik inşasına kapsamlı ve uzlaşmacı yaklaşımlar sunarlar, yerel toplulukların gerçek ihtiyaçları ve önceliklerini ifade etmelerini mümkün kılarlar (Mask- 
rey, 1989: 84; Lassa, 2018) ve yerel toplulukların bizzat kendilerinin afet hazırbulunuşluğu ve azaltımından sorumlu olabilecekleri topluluk katılımını takdir ve teşvik ederler (Lassa, 2018: 13).

Ayrıca STK'ların kırılgan toplulukların önceliklerini ve gündemlerini daha iyi anladıkları ve bunlara daha iyi yanıt verdikleri kabul edilir. STK'ların nispeten küçük organizasyon boyutlarına sahip olmalarından, daha esnek ve daha az bürokratik bir ortamda faaliyet göstermelerinden dolayı resmi kurumlara göre daha hızlı ve verimli oldukları ileri sürülür (UNISDR, 2006). STK'ların, ayrıca, bazen azınlık ve marjinal gruplarca hükümetlere nazaran daha fazla güvenildikleri, bu yüzden bu tür grupların ihtiyaçlarının belirlenmesi ve giderilmesi hususunda hükümetlere kıyasla daha başarılı oldukları da ileri sürülür (Osa, 2013: 72).

STK'ların son yıllardaki kilit gücünün en kırılgan grupları ilk sıraya koyarak toplum katılımını teşvik etmesi ve bu suretle topluluk dirençliliğini oluşturmaya çalışmasında yattığı düşünülmektedir. Bu bağlamda, örneğin Plan International, Save the Children, Dünya Vizyonu ve Çocuk Fonu gibi STK'ların çocukları ve gençleri afet risk değerlendirmesi ve afet yönetimi planlamalarına dâhil ettiklerine dikkat çekilir. Ayrıca bazı STK'ların resmi kurumlarca genellikle ihmal edilen yaşlılar ve engelli bireyler gibi kırılgan gruplar ve özel gereksinimleri üzerinde uzmanlık geliştirdikleri ve bunlara yönelik özel planlamalar yaptıklarına da vurgu yapılır. STK'ların afet yönetim süreçlerinde toplumsal cinsiyet eşitliğinin sağlanmasına hizmet ettikleri de diğer vurgular arasında yer alır. STK'ların en önemli rollerinden birisinin de modern bilgi ile yerli bilgiyi buluşturmadaki başarıları olarak görülür. Buna göre STK'lar bir yandan farklı dillerdeki uzman bilgiyi yerel topluluklara transfer ederken diğer yandan da geçmişteki tecrübelerden alınan derslerden kazanılan yerli bilgileri bilimsel bilgiyle buluşturarak afet risk azaltımına yeni katkılar sunabilmektedirler (Lassa, 2018: 13; Osa, 2013: 71).

İleri sürülen bu avantaj ve faydaları ve kendilerine atfedilen yükselişteki değer, STK'ların özellikle 1980'lerden bu yana neo-liberal politikalarla beraber küresel bir büyüme göstermesi gerçeğiyle uyum sağlar. Bu büyüme trendi hem yerel, bölgesel, ulusal 
STK'lar hem de uluslararası faaliyet gösteren STK'lar (USTK'lar) için geçerli görünmektedir. Küresel düzeyde, STK'lar Birleşmiş Milletler sisteminde de bazı önemli roller üstlenmiştir. Afet Riskini Azaltma 2005-2015 için Hyogo Eylem Çerçevesi, yerel, ulusal ve küresel düzeylerde afet risk yönetişimi platformlarının kurulmasını teşvik etmiştir ki STK'lar bu platformların birçoğunda etkili olmuştur.

Hem gelişmiş hem de gelişmekte olan ülkelerde STK'ların çoğalması, farklı ölçek ve düzeylerde afet yönetimi düzenlemesini de etkilemiştir (Tierney, 2012). Afet yönetimi alanında faaliyet yürüten STK'ların sayısındaki çoğalma, bir yandan son dönemlerde yaşanan irili ufaklı afet olaylarının sayısındaki artışla ilişkilendirilmektedir (Kent vd., 2013). STK'ların çoğalması, öte yandan, devletlerin afetler karşısında uygun ve yeterli tepki kapasitelerinin sınırlı kalmasıyla da bağlantılı görülmektedir. Bu sınırlılık karşısında STK'ların çoğalması, hükümetlerin rollerini tamamlayan "bir tür doğal tepki" olarak görülmektedir. Diğer bir deyişle, STK'ların çoğalması bir anlamda "zayıf devlet" varlığının bir sonucudur. Nitekim, genel olarak, büyük krizler ve afetler dönemlerinde, hükümet veya devlet kurumlarının mevcut risklerle başa çıkma yetkinliğinin olmaması nedeniyle STK'ların mantarlaşmasından söz edilmektedir (Zanotti, 2010; Hilhorst, 2007; Lassa, 2018). Benzer şekilde STK'ların çoğalması ve önem kazanması, ülkelerin gelişmişlik seviyeleriyle ilişkilendirilmektedir. Bu bağlamda Özerdem ve Jacoby'e göre, “UNDP'nin İnsani Gelişme Endeksi`nde çok yüksek bir yer almayan ülkelerin, genel olarak, büyük çaplı afetlere ev sahipliği yapma olasılığı daha yüksektir... Kalkınma, yönetişim ve tehlike azaltma arasındaki bu yakın ilişki, afetler ve sivil toplum arasındaki ilişkiye artan bir ilgi göstermesine neden olmuştur" (2006: 12).

Afet döngüsünde sivil toplumun devlet ile ilişkisine dair farklı yaklaşımlar olduğu görülmektedir. Bazı yazarlar bu ikisini önemli bir karşıtlık ilişkisinde tasavvur ederken bazıları da bir karşıtlıktan ziyade tamamlayıcılık ve işbirliği ilişkisi görme eğilimindedir. Örneğin Luna, (2001: 224) devlet sektörünün ve sivil toplumun, doğal afetler nedeniyle risk altında olan toplulukların direncini 
artırmak için birlikte çaba gösterebileceklerini ve bu ortak çabanın afete hazırlıklı olma durumunu artırabileceğini savunur.

Öte yandan sivil toplumun gelişme şansı her toplumda aynı değildir. Jalali'nin belirttiği gibi, "sivil işbirliği sivil yaşamının büyümesine ve gelişmesine izin verecek kuralları ve düzenlemeleri formüle edip uygulayacak kadar güçlü bir devlet gerektirir " (2002: 123). Böyle kurallar ve düzenlemelerin devlet eliyle yap1lamadığ1 toplumlarda sivil toplumun kendisi de, özellikle afet döngüsünde, beklentilerin aksine negatif etkilere yol açabilir ve yozlaşma araçlarına dönüşebilir. Devletin "güçlü bir sivil toplum" oluşumuna gönüllü olup olmaması birçok faktörce belirlenebilir. Devletin tarihsel olarak kendi toplumsal yapısıyla barışık bir ilişkisinin bulunması sivil toplumun önünü açma hususunda onu gönüllü kılabilir. Aksi bir ilişki türü devleti sivil toplum üzerinde baskıcı ve kısıtlayıcı bir tutuma yöneltebilir. Öte yandan özellikle gelişmekte olan ülkelerde, STK'ların Batılı devletler ve kuruluşlarca desteklenmesi ve onların çıkarlarıyla uyumlu çalışmalar yürütmeleri (Özerdem ve Jacoby, 2006: 19), bazı devletleri STK'lara karşı şüpheci, seçici, güvensiz ve/veya engelleyici tutumlara itebilir. Hakkında bu tür algıların oluştuğu STK'lar sadece devlet tarafından değil, onların sundukları hizmetlerin potansiyel alıcıları -yerel topluluklar- tarafından da güvensiz ve mesafeli bir ilişkiye maruz kalabilirler.

\section{Güven}

Güven, sosyal ağlarla birlikte, uzun zamandır sosyal sermaye, ekonomik işlemler ve örgütsel performansın unsurları olarak incelenmiştir. Birçok sosyal bilimci, özellikle Robert Putnam (1993, 1995), güveni ekonomik refahı teşvik eden veya önleyen ortak değerlerin gerekli bir bileşeni olarak vurgularlar. Güven, aynı zamanda, sosyal sermayenin ana bileşeni olarak da görülür. Sosyal sermaye ise, sosyal bütünleşmenin, ekonomik verimliliğin ve demokratik istikrarın gerekli bir koşulu olarak değerlendirilir (Coleman, 1988: 306; Putnam, 1993, 1995; Fukuyama, 1995).

De Tocqueville, J.S.Mill Durkheim, Simmel, Tönnies gibi teorisyenlere göre, bireysel düzeyde, vatandaşın yerel topluluğa ka- 
tılımı ve gönüllü faaliyetleri ona güven, karşılıklılık, dayanışma ve işbirliği gibi önemli sosyal davranışları öğretir. Simmel'e göre de (1950: 326), bu kavramlar serisinde merkezi rolü güven oynar; çünkü güven, "toplumdaki en önemli sentetik güçlerden biri" olarak belirir. Dolayısıyla güven, demokratik toplumun sürdürülebilirliğine elverişli kalıcı bir kültürel sendrom olarak da görülür (Inglehart 1990: 1211; Inglehart 2001). Bununla beraber güven aniden ortaya çıkan bir şey değildir. Nitekim Inglehart’a göre güven, "sabit bir genetik özellik değildir: insanların tarihsel deneyimleriyle şekillenen ve değişime tabi olan kültürel bir şeydir" (Inglehart 1990: 1211). Diğer bir deyişle güven, süreç içinde bilinçli olarak inşa edilir, tekrarlı olumlu etkileşim deneyimi ile zaman içinde kazanılır (Beratan, 2007; Longstaff ve Yang, 2008; Vasavada, 2013). Bu açıdan bakıldığında güven, kazanılması zor ve kaybedilmesi kolay bir şey olarak görülebilir.

Güven, grup içi ve gruplar arası ilişkilerde zuhur eder. Bu yönüyle güvenin varlığı ortak eylemi kolaylaştırıcı, güven yokluğu da bunu zorlaştırıcı bir etkiye sahiptir. Grup içi ve gruplar arası ilişkilerde güvenin oluşması birçok faktörle ilişkilidir. Bu faktörler aynı zamanda neden birilerine güvenildiğiyle de ilgilidir. Bu bağlamda belirgin faktörlerden birisi ortak değerlerin ve kültürün varlığ1dır. Dolayısıyla güven, ortak değerleri ve kültürü paylaşmayan yabancıların güvensizliğini de içerir (Fukuyama 1995). Paylaşılan sosyal değerler ve kimlik bir aidiyet bağı ve "biz" duygusu oluşturmak suretiyle topluluk/grup üyelerine olan güveni ve dolay1sıyla işbirlikçi davranışı arttırır (Tyler ve Degoey, 1995). Öte yandan bu aidiyet bağı ve "biz" duygusu temel bir varsayımla işlerlik kazanır. Hogg'un (2007) belirttiği gibi, grup üyelerinin "bizden biri" olduklarında bize zarar vermemeleri ve grubumuzu koruyan ve teşvik eden davranışlar sergilemelerine güveniriz.

Grup içi ve gruplar arası ilişkilerde güvenin oluşmasını etkileyen bir başka faktör de güvene konu olan meseleyle ilgili bilgi/beceri düzeyidir. Buna göre, insanlar uzmanlık sahibi olmadıkları bir alanda karar vermek zorunda kaldıklarında, tek seçenekleri gü- 
venilir olarak gördükleri uzmanlara ya da aktörlere güvenmektir. Başka bir deyişle, bazen birilerine güvenmekten başka çare yoktur ve kültürel biliş güvenilirlik algısını etkilemektedir (Kahan vd., 2011). Bu nedenle denilebilir ki güven risk içerir (Luhmann, 1988). Potansiyel risklerine rağmen güven, çoğu insanın yaşamının büyük bir kısmında vazgeçemediği bir şeydir çünkü güven olmadan sosyal yaşam tahammül edilemez ve büyük ihtimalle imkânsız olurdu (bir taksiye binmek bile şoförünün sürücülükte ne kadar mahir olduğunu bilmememize rağmen yaptığımız güvene dayalı bir eylemdir).

Birilerine güvenmekten başka çaremiz yoksa kırılgan bir durumdayız demektir. Nitekim bazı araştırmacılara göre, kişisel kırılganlık güvenin merkezinde yatar. Eğer kendimizi kırılgan hissetmiyorsak, muhtemelen insanlara güvenme ihtiyacını da hissetmeyiz (Hogg, 2007).

Yukarıdaki genel tespitlerden anlaşllıyor ki güven, doğrudan afet yönetişimiyle de ilgilidir. Güven temelli ilişkiler, afet de dahil olmak üzere, etkili acil durum müdahaleleri için kritik öneme sahip görülür (Janssen vd., 2010; Kapucu ve Garayev, 2011; Longstaff ve Yang, 2008).

Bireyler ve kurumlar afet öncesinde, sirasında ve sonrasında afetle ilgili iletişim ve etkileşim içerisinde bulunurlar. Bu süreçlerde aktörler birçok bilgiler, duyumlar ve kanaatler paylaşırlar. Paylaşımlar birebir ilişkiler, kulaktan duyma, geleneksel medya ve / veya sosyal medya üzerinden gerçekleşebilir.

Afet döngüsü içerisinde doğru, eksik, abartılı, hatalı, kurgusal ve kasıtlı bilgi ve iddialar dolaşıma girebilir. Bazen resmi kurumlar, Dynes'in (2002: 17) vurguladığı gibi, çeşitli nedenlerle (ör. halkı paniğe sokmama kaygısıyla) bazı bilgileri gizli tutulabilir. Palttala vd. (2012), doğru, yaygın ve zamanında bilgi kullanımının kaygıyı azalttığı ve insanların öz-yeterlik duygusunu güçlendirdiği sonucuna varmıştır. Bu şekilde güven, tüm kriz aşamalarındaki eylemlerin ve iletişim akışının bir sonucu olarak görülür (Longstaff ve Yang, 2008; Palttala vd., 2012). Bazen de gerçek veya olası 
bir afet bazı çevrelerce fırsat olarak görülebilir ve çıkar amaçlı söylenti ve söylemlere aracılık edebilir.

Dolayısıyla afet döngüsünde bireylerin, hanehalklarının ve diğer tüm paydaşların gerçek veya olası afetlerle ilgili doğru/güvenilir bilgiye ihtiyaçları doğar. Bu ihtiyaç aktörlerin ne zaman, hangi eylemlere yönelecekleriyle doğrudan ilgilidir. Bu nedenle bireylerin, hanehalklarının ve yerel toplulukların afet döngüsünde doğru bilgi için kime güvenecekleri büyük önem arz eder.

Konunun ikinci boyutu, gerektiğinde kimden yardım alınabileceği, diğer bir deyişle yardım için kime güvenileceğiyle ilgilidir. Arama-kurtarma, gıda, barınma, sağlık, eğitim, psikolojik destek, ulaşım ve iletişim vb. yardım hususları özellikle afet sırasında ve sonrasında afetzedelerin önemli ve acil ihtiyaçları arasında yer alır. Bunların yanı sıra, afete müdahale ve iyileşme merhalelerinden sonra tekrar benzer yıkımlar, kayıplar, acılar yaşanmaması için gerekli analizler, önlemler ve hazırlıkların yapılması ve yerel toplulukların afete dirençlerinin arttırılması da gerçek veya olası afetzedelerin beklentileri arasında yer alır.

Gerek bilgi gerekse yardım kaynağı olarak güvenilebilecek başl1ca kaynaklar akrabalar, arkadaşlar, komşular gibi birebir ilişkilere dayalı aktörler ve/veya yerel ve ulusal medya, sosyal medya, sivil toplum örgütleri, dini kurumlar ve cemaatler gibi gayri resmi aktörler olabileceği gibi valilikler/kaymakamlıklar (AFAD), belediyeler gibi resmi kurumlar ve kuruluşlar da olabilir.

Afet yönetişimi tüm bu aktörlerin etkili ve verimli iletişim ve işbirliğini gerektirir. Bunun yanı sıra, sayılan muhtemel hizmet sağlayıcı aktörlerin hizmet ettikleri topluluklar tarafından güvenilmesi de önemlidir (Longstaff ve Yang, 2008). Ayrıca hizmet süreçlerinde güvenin, koordinasyonu kolaylaştırdığı, hızlandırdığı ve başarılı bir afet yönetiminde kilit faktör olduğu kabul edilir (Kapucu, 2005; Moe ve Pathranarakul, 2006).

\section{Türkiye'de Afet Yöneti(şi)mi, Sivil Toplum ve Güven Algıları}

1999 Marmara Depremleri, daha önce hiç olmadığı kadar gazetecilerin, sosyal bilimcilerin ve politikacıların Türkiye'de afet 
yönetimi, devlet ve sivil toplum ilişkileri üzerine yeni söylemler üretmelerine vesile olmuştur. Akgüngör'ün (2010) deyişiyle bu acı tecrübe, afetlerle ilgili olarak Türk aydınlarının devlete ve sivil topluma bakışında köklü dönüşüm yaratan bir "milat" olmuştur. Nitekim bu milat anlayışı birçok yazar tarafından paylaşılan bir eğilimdir (Jalali, 2002; Yavaş, 2005; Özerdem ve Jacoby, 2006; Akgüngör, 2010; Odabaş, tarihsiz).

Akgüngör, bu dönüşümü gazeteciler üzerinden incelemiş ve depreme hazırlıksız yakalandı̆̆ı, olanaklarının yetersiz ve müdahalelerinin gecikmeli olduğu gözlenen devletin "ataerkil”, "baba”, "her şeye gücü yeten" devlet imgesininin çok ciddi biçimde sarsıldığına, bu durum karşısında ortaya çıan "gönüllü akınından" gazetecilerin süratle bir "sivil toplum" söylemi geliştirdiklerine ve özellikle Arama ve Kurtarma Derneği'ni (AKUT), kısa zamanda "sivil toplumun öncüsü ve temsilcisi" olarak göstermeye başladıklarına dikkat çeker (2010: 9-14). Ona göre, 1999 Marmara depremleri bağlamında sivil toplum, meşruluğu sorgulanmakta olan rejimin, siyasetin ve kamu yönetiminin antitezi olarak, "değişimin meşru aktörü" olarak sunulmuştur. Ancak depremin etkisi geçtikten sonra bu söylemlerin de etkisi kaybolmuştur; netice olarak Türkiye bağlamında yurttaşların 'devlet' karşısında hala güçsüz olması nedeniyle medya kaynaklı eleştirilerin siyasi sonuçları "yok denilecek kadar sınırlı" kalmaktadır (Akgüngör, 2010: 1519). Bu görüşlere paralel olarak, Türkiye'de devlete ilişkin "ihtiyaç zamanlarında vatandaşlarını koruyabilecek bir 'baba' figürü" şeklindeki hâkim algının, "depremin yıkımı ve Ankara'nın tepkisinin yetersizliği ile ezildiğini" ileri süren Özerdem ve Jacoby (2006: 99) de "Marmara depremi tarafından katalize edilen ve Türkiye'nin AB'ye katılım çabalarıyla daha da güçlenen değişim süreçleri "devlet baba" geleneğini yıkmış olabilir, ancak henüz devletin patrimonializmini daha çoğulcu bir yönetişim modeliyle değiştirmemiş olabilirler" değerlendirmesini yapmaktadırlar (Özerdem ve Jacoby (2006: 109).

Türkiye'de 1999 Marmara depremlerinin devlet-sivil toplum ilişkisine dair algıları nasıl değiştirdiğine odaklanan Jalali (2002) de, bu deneyimden sonra Türkiye'de yardıma ulaşma konusunda 
devletin ve siyasi otoritenin yetersiz kalmasının depremzedelerde devlete ve siyasi otoriteye karşı güven kırılması yarattığını, buna karşın STK'ların etkinlik ve önem kazandığını, etkin bir afet yönetişimi için devlet-sivil toplum işbirliğinin ideal bir sistem yaratacağını ileri sürer.

1999 Marmara depremleriyle birlikte ortaya çıtı̆̆ı düşünülen bir sivil toplum sempatisine rağmen Türkiye'de afet analizcileri hala "baba" rolüyle merkeziyetçi gücünü ve rolünü sürdüren bir devlet görme ve bu durumu afet yönetimi açısından negatif bir şey olarak değerlendirme eğilimindedirler. Nitekim birçok yazar Türkiye'de afet yönetiminin başat aktörünün devlet olduğunu, sivil toplumun bu süreçte aktif rol alabilmesi için gerekli koşulların sağlanmadığı görüşünü paylaşmaktadır (Tarih Vakfı, 2000; Kubicek, 2002; Ganapati; 2005; Özerdem ve Jacoby, 2006). Örneğin Yavaş’a göre “Türkiye' nin Tanzimat'tan günümüze en önemli sorununun güçlü merkeziyetçilik olduğu söylenebilir" (2005: 287). Türk Kamu yönetimi sisteminde afet yönetim yetkisinin valilikler/kaymakamlıklarda toplanması, belediyelere sadece yardımcı bir rol verilmesi, Yavaş'a göre, son yarım yüzyılda içinde meydana gelen doğal afetlerdeki can ve mal kayıplarının gösterdiği gibi, sadece başarısızlık üretmiştir. Dolayısıyla merkeziyetçi mirası bırakıp sorunlara çözüm için "kamu-özel-sivil ortaklığı çerçevesinde katılımcı ve birlikte yönetim anlayışını vurgulayan yeni yönetim stratejilerinin hayata geçirilmesi" gerekmektedir (2005: 288). “'Devlet baba' anlayışı sistemin her aşamasında kendini gösteren en belirgin özelliktir ve tamamen değiştirilmesi en zor unsurdur" diyen Yavaş'a göre, "afetten etkilenmiş toplumda 'doğal bir afet olduğunda devlet acilen müdahale eder ve ihtiyaçları giderir, ayrıca yaşadıkları çevreyi eski haline getirir' şeklinde bir izlenim bulunmaktadır. Bu izlenim doğal olarak bir risk altındaki toplum gruplarında olaylara karşı seyirci kalma eğilimi oluşturmaktadır" (2005: 290).

Türkiye'nin merkeziyetçi/devletçi bir modeli temsil ettiğini düşünen Özerdem ve Jacoby, doğal afet yönetiminde siyasi elitlerin "üçüncü sektöre tamamen kurumsallaşmış ve son derece katı kısıtlamalar getirdiğini", "insani yardımın politikleşmesine dair 
devlette genel bir korku" bulunduğunu, "sivil toplumun zayıfl1ğının, devletin baskısından kaynaklandığını" ileri sürerler (Özerdem ve Jacoby, 2006: 99-107; ayrica bkz. Jalali, 2002). Dolayısıyla Türkiye'de afet yönetişiminin gelişememesinin ana sorumlusu olarak devlet görülür ve bu eğilim oldukça yaygındır. "Güçlü ve ceberut devlet geleneği" ile "zayıf sivil toplum" ilişkisinden kaynaklanan "merkeziyetçi ve başarısız afet yönetimi pratikleri" afetlere karşı güvenlik açıkları yaratmaktadır (Aydıner ve Özgür, 2014: 400).

Görülüyor ki, merkeziyetçi geleneğine atıfla Türkiye'de devlet, afet yönetim süreçleri (azaltım, hazırbulunuşluk, müdahale, iyileşme) bağlamında hala afetzedelere afet sonrası yardım odaklı bir pozisyonu korumak, yönetişim ilkesinden uzak kalmak, sivil toplum ile etkili ve yeterli bir işbirliği yapmamak ve sivil topluma güvenmemek ile nitelendirilmektedir. Bu nitelemeler, afet yönetim döngüsündeki başarısızlıklar ve yetersizliklerden temelde devleti sorumlu tutmak anlamına gelmektedir. Bu tür çözümlemeler aynı zamanda Türkiye'de afet yönetişim süreçlerinde en önemli sorunlardan birisinin aktörler arası güvensizlik olduğuna da işaret etmektedir. Buna göre bir yandan toplum devlete karşı güven kırılmasına uğramış bulunmaktadır, diğer yandan da devlet toplumun bazı kesimlerine ve bu arada sivil toplum kuruluşlarına karşı güvensiz bir tutum içindedir. Bu karşılıklı güvensizlik afet yönetişimin gelişme olanaklarını kısıtlamaktadır. Odabaş'ın vurguladığı gibi 1999 Marmara depremlerinden sonra "aradan geçen 15 yıla rağmen bu konuda bir değişimin yaşanmaması, toplumsal hafızanın düşük olması, gündemin çabucak değişmesi Türkiye'de sürdürülebilir bir afet yönetimi oluşturmada önemli engeller teşkil etmektedirler." Türkiye' de toplum, devlete güvenmemektedir, bunun yerine bir başa çıkma mekanizması olarak "Allah'a güven" duymaktadır (Odabaş, tarihsiz: 32).

2011 Van ve Erciş depremleriyle ilgili gerçekleştirilen bir çalışmasinda Hermansson (2016) da devlet ve Van belediye otoriteleri arasındaki önceki negatif ilişkilerin ve güven eksikliğinin hasar değerlendirme işbirliğini verimsiz kıldığını, benzer bir durumun Van'ın deprem sonrası iyileşme sürecinde de yaşandığını ve pay- 
daşların bu süreçte rol almasının siyasal gerilim tarafından engellendiğini ileri sürer (ayrıca bkz. Platt ve Durmaz, 2015). Ancak Hermansson'ın bu çalışması da ağırlıklı olarak yine devletin sivil ve yerel topluma güvensizliğine odaklanan bir çalışma olarak kalmaktadir.

Zikredilen bu çalışmalar, özet olarak, merkezi devletin sivil topluma güvensizliğini kabul etmekte ama toplumsal tabanda sivil topluma karşı yüksek bir güvenin olduğunu ima etmektedir. Yerel yönetimlerin merkezi devlete ve sivil topluma ne düzeyde güvendikleri ve onlarla ne kadar işbirliği içinde oldukları ise nispeten muğlak bir alandır. Ayrıca bu çalışmalar 'güçlü devlet' anlayışının "zayıf sivil toplum" sonucunu ürettiğini, bunun da etkisiz ve verimsiz bir afet yönetimine yol açtığını bazen açık bazen de örtük bir şekilde savunmaktadırlar. Ne var ki bu savların birço$\breve{g u}$, özellikle toplumsal tabanın (hanehalklarının) ve yerel yönetimlerin sivil topluma güveniyle ilgili olanları, görgül verilerle sınanmaya muhtaçtır. Böyle bir sınamayı amaçlayan çalışmalar Türkiye bağlamında çok sınırlıdır. 1999 Marmara depremleri sonrasında basında bir süre yer alan sivil topluma ilgi ve güven belirtilerinin hala toplumsal tabanda devam ettiği düşüncesinin bir varsayım mı yoksa bir gerçeklik mi olduğu sorgulanmayı gerektirmektedir.

\section{Araştırma Amaç, Yöntem ve Teknikleri}

\section{Araştırmanın Amaç ve Problemi}

Yukarıda belirlenen kavramsal çerçeve, öncelikli olarak STK'lar, yerel yönetimler ve merkezi devlet kurumları arasında güvene dayalı ilişkiler, pozitif önsel deneyimler, etkili iletişim ve işbirliği mevcut olduğu takdirde başarılı sonuçlar yaratan bir yönetişimin gerçekleşeceğini, bununla beraber afet yönetim performansının tarihsel ve toplumsal bağlama göre değişebileceğini göstermektedir. Betimlenen kavramsal çerçeve aynı zamanda "zayıf sivil toplum" ve "başarısız afet yönetiminin", merkeziyetçi/devletçi siyasal sistemin ürettiği gerçekler olduğunu varsaymaktadır. Bu varsayımın kilit noktası, afet yönetimindeki aktörlerin birbirlerine ilişkin güven algılarıdır. Güven varsa, afet risk azaltımı süreçle- 
rinde aktörler arası iletişim ve işbirliği daha kolay, hızlı ve etkili bir şekilde gerçekleşir. Güven yoksa, genellikle yetersiz/başarısız sonuçlar doğar. Merkeziyetçi/devletçi siyasal sistem sivil topluma güvenmese de sivil toplum toplumsal tabanın güvenini kazanmayı hedefler. Bununla birlikte, “STK'lar kendilerini yerel toplumun ve yönetişimin gerçek ortakları olarak görebilirler, ancak çoğu durumda aynı görüş halk tarafından paylaşılmaz" (Shaw ve Goda, 2004: 32). Diğer bir deyişle STK'lar, sadece devletin gözünde değil, aynı zamanda toplumsal tabanın gözünde de güven krizi yaşayabilirler. Elbette böyle bir kriz afet risk yönetimine negatif etkiler yapacaktır.

Bu makale afet yönetişiminde aktif rol almaları beklenen aktörler arasındaki güven algılarının güncel durumunu incelemeyi ve bu suretle "güçlü devlet" ve "zayıf sivil toplum" kavramları çerçevesindeki kuramsal önermelerin doğruluğunu görgül verilerle sınamayı amaçlamaktadır. Bu amaçlar doğrultusunda makalenin odaklandığı ana araştırma sorusu şöyle ifade edilebilir: 2020 yılı itibariyle Türkiye' de afet yönetişimi aktörlerinin birbirlerine güven ve işbirliği hususunda fiili durumları ne yöndedir? Varsa, güvensizlik tek yönlü mü, karşılıklı mıdır? Spesifik olarak toplumsal tabanın ve yerel yönetimlerin devlet kurumlarına ve sivil topluma güven durumları nasıldır?

\section{Araştırma Yöntem ve Teknikleri}

Araştırma, TÜBİTAK tarafından desteklenen çok boyutlu bir araştırmanın bir parçasını oluşturmaktadır. Spesifik olarak bu makalenin temel sorunsalı, afet yönetişiminde yakın iletişim içinde işbirliği yapmaları ve sorumlulukları paylaşmaları beklenen aktörlerin ne tür güven algılarına sahip olduklarıdır. Güven kavramı; a) bilgi kaynağı olarak güven duyulan aktörler, b) yardım kaynağı olarak güven duyulan aktörler bağlamında incelenmiştir. İncelemeye dâhil edilen aktörler yerel topluluk üyelerini, yerel yönetimleri ve merkezi devlet kurumlarını temsil edecek örneklemler arasından seçilmiştir. Böylece, a) hanehalklarının güven algıları, b) muhtarların güven algıları, c) belediye yöneticilerinin güven algıları, d) AFAD yöneticilerinin güven algıları araştırma kapsa- 
mina alınmıştır. Sayılan bu aktörlerin özellikle sivil toplum örgütlerine yönelik güven algıları araştırmanın odak noktasını oluşturmaktadır. Sivil toplum örgütlerinin diğer aktörler hakkındaki güven algıları ise araştırmanın kapsamı dışındadır.

$\mathrm{Bu}$ araştırmada yöntemsel çoğulculuk yaklaşımı benimsenmiştir. Yerel topluluk üyelerinin güven algılarını incelemek için nicel bir yöntem, yerel yönetimlerin (muhtarlar ve belediyeler) güven algılarını ve merkezi devlet kurumlarının (Valiliğe bağlı hizmet yürüten $\mathrm{AFAD}$ ) güven algılarını incelemek için de nitel bir yöntem uygulanmıştır.

Hanehalklarının güven algılarını incelemeyi amaçlayan nicel araştırma, deneklerin bilgi ve yardım kaynağı olarak güven duymaları muhtemel çeşitli aktörlerle ilgili bir anket formunu veri toplama aracı olarak kullanırken yerel ve resmi yönetimlerin güven alg1larını incelemeyi amaçlayan nitel araştırma, açık uçlu sorulardan oluşan yarı-yapılandırılmış bir mülakat formunu kullanmıştır. Nicel verilerin SPSS programı üzerinden veri girişleri ve analizleri yapılmıştır. Mülakatlar ses kayıt cihazına kaydedilmiş ve ardından deşifrasyonu yapılmış, elde edilen veriler tematik sınıflamaya ve analize tabi tutulmuştur. Mülakatlar 30-60 dakika arasında değişen sürelerde gerçekleştirilmiştir. Nicel ve nitel verilerin toplandığı saha çalışması 2018 yılında Balıkesir'in merkez, kıyı ve iç/ karasal ilçelerini temsil eden 12 ilçesinde gerçekleştirilmiştir.

\section{Araştırma Evren ve Örneklemi}

Araştırmanın çalışma evreni Balıkesir'deki hanehalkları, muhtarlar, belediye yöneticileri ve afet yönetiminde doğrudan sorumluluğu olan resmi kurumlardır. Balıkesir'in çalışma evreni olarak seçilmesinin nedeni, deprem ve sel başta olmak üzere, birçok doğal afet riskinin yoğun olduğu illerden birisi olmasıdır. Marmara ve Ege bölgeleri arasında bir geçiş noktasında yer alan Balıkesir, ayrıca, demografik özellikleri itibariyle de çeşitlilik gösteren (yaş grupları, etnik ve mezhepsel çoğulluk, sosyo-ekonomik düzeyler ve kültürel çeşitlilik vb.) ve afet alg1, tutum ve davranışlarındaki muhtemel çeşitliliğin izlenebileceği illerden birisidir. 
Tablo 1: Analiz birimleri, araştırma türü, evren, örneklem türü ve büyüklükleri

\begin{tabular}{|c|c|c|c|c|}
\hline Analiz Birimi & $\begin{array}{c}\text { Araştırma } \\
\text { Türü }\end{array}$ & Evren & $\begin{array}{c}\text { Örneklem } \\
\text { Türü }\end{array}$ & $\begin{array}{c}\text { Örneklem } \\
\text { Büyüklüğü }\end{array}$ \\
\hline Hanehalkı & Nicel & $395499^{*}$ & Rastlantısal & 1139 \\
\hline Muhtarlar & Nitel & $1129^{* *}$ & Amaçlı & 50 \\
\hline Belediyeler & Nitel & $53^{* * *}$ & Amaçlı & 10 \\
\hline AFAD yöneticileri & Nitel & $6^{* * *}$ & Amaçlı & 3 \\
\hline
\end{tabular}

Kaynaklar:

* TUiK 2016

** http://www.muhtarlarkonfederasyonu.org/il-muhtarlari.html

*** GYODER 2015

**** https:/ / balikesir.afad.gov.tr/teskilat-semasi

Bu çerçevede araştırmanın analiz birimleri olarak nicel araştırma için hanehalkları, nitel araştırma için ise muhtarlar, belediye yöneticileri ve AFAD yöneticileri kullanılmıştır. Tablo 1, bu analiz birimleri bağlamında çalışma evreninin ve örneklem büyüklüklerinin sayısını sunmaktadır. Buna göre Balıkesir' deki 395499 haneyi temsilen 1139 kişiyle anket yapılmıştır. Ek olarak, amaçlı örneklem yöntemiyle 1129 muhtarı temsilen 50 muhtarla; 53 belediyeyi temsilen 10 belediye yöneticisi ve AFAD yöneticilerini temsilen de 3 yöneticiyle mülakatlar yapılmıştır.

\section{Bulgular}

\section{Hanehalklarının Güven Algıları}

1) Doğru Bilgi İçin Güven Duyulan Aktörler

Deneklerin afetlerle ilgili kendilerine doğru bilgi vereceğine güvendikleri aktörler içerisinde arkadaşlar ve akrabalar (\%80 ve \%77), komşular (\%74) ve yaklaşık onlar kadar resmi kurum ve kuruluşlar (ordu: \%78; emniyet:\%79; Belediye: \%77,5; Valilik/ AFAD: \%77 ve diğer resmi kurumlar: \%71) oldukça yüksek oranlarla önde gelmektedir (bkz. Tablo 2). 
Tablo 2: Doğru Bilgi İçin Güven Duyulan Aktörler

\begin{tabular}{|l|c|c|c|c|}
\hline $\begin{array}{c}\text { Bir Afet Durumunda } \\
\text { Doğru Bilgi Iç̧in Güven } \\
\text { Duyulan Aktörler }\end{array}$ & $\begin{array}{c}\text { Evet/ } \\
\text { Kesinlikle } \\
\text { Evet } \%\end{array}$ & $\begin{array}{c}\text { Hayır/ } \\
\text { Kesinlikle } \\
\text { Hayır } \%\end{array}$ & $\begin{array}{c}\text { Cevapsız } \\
\%\end{array}$ & $\begin{array}{c}\text { Toplam } \\
\%\end{array}$ \\
\hline Arkadaşlarınız & 79,7 & 18,5 & 1,8 & 100 \\
\hline Akrabalarınız & 76,9 & 21,7 & 1,4 & 100 \\
\hline Komşularınız & 73,9 & 23,5 & 2,6 & 100 \\
\hline Sivil toplum kuruluşları & 56,2 & 41,1 & 2,7 & 100 \\
\hline Ordu & 77,8 & 20,4 & 1,8 & 100 \\
\hline Emniyet & 79,2 & 19 & 1,8 & 100 \\
\hline Belediye & 77,5 & 21,1 & 1,4 & 100 \\
\hline Valilik/AFAD & 77,3 & 21,2 & 1,5 & 100 \\
\hline Diğer resmi kurumlar & 71 & 26,3 & 2,7 & 100 \\
\hline Ulusal medya & 65,1 & 33,8 & 1,1 & 100 \\
\hline Yerel medya & 56,1 & 42,8 & 1,1 & 100 \\
\hline
\end{tabular}

Bununla birlikte deneklerin yaklaşık \%20'sinin bu sayılan aktörlerin verecekleri bilgilerin güvenirliğine kuşkuyla baktığı anlaşılmaktadır. Öte yandan sivil toplum kuruluşlarının ve yerel medyanın vereceği bilgileri güvenilir bulanlar ise en az oranlara sahiptir (her ikisi de \%56). Ulusal medyanın vereceği bilgileri güvenilir bulanlar ortalama bir oran (\%65) sergilemektedirler. Bu veriler göstermektedir ki hanehalkları afetlerle ilgili doğru bilgi edinmek için birincil gruplarına ve devlet kurumlarına güvenmekte, medyaya ve sivil toplum kuruluşlarına kuşkuyla yaklaşmaktadır. Dolayısıyla 1999 depremlerinden bu yana çok şeyin değişmiş oldu$\breve{g u}$, bu süreçte afetlerle ilgili bilgiler açısından medyanın ve sivil toplum kuruluşlarının kredibilite kaybına uğradığı söylenebilir.

2) Yardım İçin Güven Duyulan Aktörler

Güvenilir bilgi hakkında söylenenler bir afet durumunda yeterli yardım edeceğine güvenilen aktörler için de söylenebilir (bkz. Tablo 3). Nitekim; 
- Araştırma bulgularına göre Balıkesir'de hanehalklarının yüz yüze ilişki içinde bulundukları arkadaşlar, akrabalar ve komşularının kedilerine yeterli yardım yapacaklarına güvenmektedirler $(\% 85+)$.

- Ayrica bulgular hanehalklarının hemen hemen tüm devlet kurumlarının, belediyelerin ve Kızılay'ın muhtemel bir afet durumunda kendilerine yeterli yardımı yapacaklarını göstermektedir $(\% 79+)$.

- Buna karşılık Kızılay haricindeki diğer sivil toplum kuruluşlarının yeterli yardım yapacağına güvenenlerin oranı $\% 66{ }^{\prime}$ da kalmıştır.

- Dini cemaatlerin bir afet durumunda kendilerine yardım yapacağına güvenenlerin oranı ise sadece $\% 32,6^{\prime}$ dır.

Tablo 3: Yardım için Güven Duyulan Aktörler

\begin{tabular}{|l|c|c|c|c|}
\hline $\begin{array}{c}\text { Bir Afet Durumunda } \\
\text { Yardım için Güven } \\
\text { Duyulan Aktörler }\end{array}$ & $\begin{array}{c}\text { Evet/ } \\
\text { Kesinlikle } \\
\text { Evet } \%\end{array}$ & $\begin{array}{c}\text { Hayır/ } \\
\text { Kesinlikle } \\
\text { Hayır } \%\end{array}$ & Cevapsız \% & Toplam \% \\
\hline Arkadaşlarınız & 88,6 & 9,1 & 2,3 & 100 \\
\hline Akrabalarınız & 88,2 & 10,1 & 1,7 & 100 \\
\hline Komşularınız & 85 & 12,3 & 2,7 & 100 \\
\hline Dini cemaatler & 32,6 & 64 & 3,4 & 100 \\
\hline Kizılay & 91,9 & 6,9 & 1,2 & 100 \\
\hline Sivil toplum kuruluşları & 66 & 31,2 & 2,8 & 100 \\
\hline Ordu & 84,4 & 13,5 & 2,1 & 100 \\
\hline Emniyet & 82,6 & 15,3 & 2,1 & 100 \\
\hline Belediye & 78,9 & 19,3 & 1,8 & 100 \\
\hline Valilik/AFAD & 83,2 & 16,2 & 0,6 & 100 \\
\hline Diğer resmi kurumlar & 77 & 19,6 & 3,4 & 100 \\
\hline
\end{tabular}


Dikkat edileceği üzere bir afet durumunda yeterli yardım edeceğine güvenilen aktörlerle ilgili soruya "dini cemaatler" seçeneği de eklenmiş ve hanehalklarının dini cemaatlerin yardım edeceğine güvenip güvenmediği öğrenilmek istenmiştir. Batılı ülkelerde Kilise en önde gelen yardım kuruluşları arasında olmasına rağmen Balıkesirli hanehalkları \%64 gibi oldukça yüksek bir oranda dini cemaatlerin afetzedelere yardım edeceğine güvenmemektedirler.

\section{Muhtarların Güven Algıları}

Muhtarlara yerel topluluklarda afet hazırbulunuşluğunu geliştirme yönünde faaliyetler yürüten STK'larla herhangi bir irtibat ve işbirliklerinin bulunup bulunmadığı sorusu yöneltildi. Muhtarların büyük bir çoğunluğu STK temsilcileriyle sadece birkaç kez verilen seminerlerde bir araya gelme fırsatı bulduklarını ifade etmişlerdir:

Sadece seminerlerde, ilk yardım uygulamalarnda filan irtibatımız oldu, başka da olmadı. Çağırırlarsa gidiyoruz öylelikle oluyor. (erkek,51 yaşında, 8 yillık muhtar)

Şurada aşă̆ıda bir okul var... orda bir seminer verdiler. İmamımız, ben, seçtiğimiz vatandaşlar oldu; onlarla birlikte bir eğitim semineri gibi bir şey almıştık acil durumlar hakkında. (erkek, 49 yaşında, 8 yillik muhtar)

Görüldüğü üzere, mahalle muhtarları ile STK'lar veya gönüllü kuruluşların ortak etkinlik olasılıkları yalnızca bazı seminerlerde karşılaşmadan ibaret olup, birlikte aktif bir çalışma eğilimleri görülmemektedir. Muhtarların birkaçı ise sivil toplum ve gönüllü kuruluşlarla irtibat halinde olduklarını ve bu tür çalışmalarda bulunduklarını belirtmişlerdir.

Evet, evet hiç irtibatımız kesilmiyor bu kuruluşlarla, zaten kaymakam Bey de zaman zaman topluyor. Hatta geçenlerde bir yenisini daha yaptık tüm ilçe muhtarları ve Kaymakam bey ile değerlendirme yaptık bu doğal afetlerle ilgili, ama sivil toplum kuruluşlarıla da sürekli görüşüyoruz yani. Toplantılar, değerlendirmeler veya işte seminerler yapılıyor, bunlara katılıyoruz. (erkek, 62 yaşında, 8 yıllık muhtar). 
Genel olarak, muhtarların STK'larla ilişkilerinin sadece birkaç seminer ve toplantıda bir araya gelmekten ibaret olduğu söylenebilir. Ayrıca muhtarların STK'lardan daha çok devletin kurum ve kuruluşlarıyla işbirliği ve çalışma içerisinde oldukları görülmektedir.

Muhtarlara muhtemel bir afet durumunda mahalleleri için ihtiyaç duyulan yardım ve desteği sağlayacak kurum/kuruluşlar içerisinde (Valilik, Belediye, Sivil Toplum Kuruluşları seçenekleri kapsamında) en çok hangilerine güvendikleri de soruldu. Bu soruya muhtarlarının çoğu afet durumunda en çok Belediyelerin kendilerine yardım ve destek sunacağ mahiyetteki yanıtlardan bazıları şöyledir:

Biz halk olarak birakın burada olmasın Van'da bile deprem olsa yardım ederiz zaten. Valiliğe güvenirim, Kızılay'a, Belediyeye hepsine güvenirim onlar bizim babalarımı sonuçta. Ama tabi bizim başımız sıkıştığında hemen Karesi Belediyesi'ne gideriz ya da ararız. Ĕger orayı aşan bir durum olursa Büyükşehir Belediyeye gideriz. Yani en çok güven duyduğumuz Belediye denilebilir. (erkek, 49 yaşında, 8 yillık muhtar)

Valilik, Kaymakamlık olsun sosyal devlet anlayışın yerine tam olarak getiriyorlar. Ama özellikle Karesi Belediyesi vatandaşlarnna hizmeti tam anlamıyla sunuyor. Kızılay' dır, Akut'tur yani bu gibi sivil toplum kuruluşlarma tam bir güvenim yok. Belki de henüz böyle büyük bir afete maruz kalmadığım için başıma gelmediği için olabilir. Ama bana yani devlet kurumlar, sosyal devlet daha çok güven veriyor. En çok Belediyeye, Karesi Belediyemize güven duyuyorum bu konuda. (kadın, 52 yaşında, 4 yıllık muhtar)

Yukarıdaki ifadelerde dikkat çeken husus, muhtarların sivil toplum kuruluşlarına pek fazla güvenmemeleri, buna karşı devletin kurumlarına daha fazla güven duymalarıdır. Yapılan başka araştırmalarda da (YADA, 2014: 18) STK'ların itibarını etkileyen faktörlerin \%66'sının olumsuz nitelikli olduğu görülmüştür. STK'lar hakkında 'ideolojik olmak', 'çıkar odaklı olmak', 'pasiflik' gibi olumsuz niteliklerin sıklıkla vurgulanması, itibarın negatif inşası hakkında önemli fikir vermektedir. 
Muhtarların en çok belediyelerin yardım ve destek sağlayacağına güven duymasında etkili unsurlardan birisinin vatandaşların görüş ya da taleplerinin tek bir merkezde toplanmasını sağlayan Beyaz Masa uygulaması olduğu anlaşılmaktadır. Örneğin bir muhtar buna şöyle dikkat çekmektedir:

En çok Belediyenin bize hizmet vereceğini, destek olacağını düşünüyorum. İlçe Belediyemize, Büyükşehir Belediyesi'ne en ufak bir durum olduğunda beyaz masayı arıyoruz zaten, gerek kendimiz gerek vatandaşımızla ilgili, anında ilgileniyorlar sağ olsunlar. O yüzden Belediye diyorum en çok güvendiğim. En çok bize Belediye yardım eder. (erkek, 64 yaşında, 3 yıllık muhtar)

Öte yandan muhtarlar içerisinde muhtemel bir afet durumunda Balıkesir halkına en çok Valiliğin destek ve katkı sağlayacağını düşünenler de bulunmaktadır. Bir muhtara göre:

Valiliğe, belediyeye, sivil toplum kuruluşlarnna hepsine güven duyuyorum tabi ama en çok Valiliğe güven duyuyorum. Çünkü yetki olarak da zaten Balıkesir'de en üst mevki olarak onlar yardımcı olurlar bize. (erkek, 67 yaşında, 25 yıllık muhtar)

$\mathrm{Bu}$ görüşlerin tam aksine ne Valiliğin ne de belediyelerin sahip oldukları yetkilere rağmen vatandaşa hizmet sağlamadığını düşünen birkaç muhtar da bulunmaktadır. Aşağıdaki alıntı bu düşünceyi örnekleyecek niteliktedir.

Şöyle bir şey var. Ben mesela ylllar önce valilik bize bir brifing verdi. 2005-2006 yilları gibi. Konuştu, doğal afetle ilgili anlattı. Sivil Savunma Müdürlüğ̈üydü sanırım. Ben de söz istedim dedim sayın Valim bakın 1999 depremi 5-6 senelik mevzu, dünya kadar can gitti. Kalanlar ikinci bir deprem yaşadı ama ne bir kanalizasyon ne de barnacak yer ne su var. Insanlar kendi hallerine terk edildi, dumanı çıtı insanların dedim. Sokaklar tıkandı insanlar kımıldayamadı. Bize büyük bir deprem olsa nerde toplanacak bu insanlar, bu bölgede 5-10 bin çadır kurulabilecek mi. Buraların kanalizasyonu hazır döşenmiş mi, su ihtiyaçlar bu alanda giderilebilecek mi dedim. Konuştum işte anlattım. Sonra Vali bey döndü müdüre, hadi cevap ver muhtarıma dedi. Cevap var mı yok. Çünkü uygulamada yok. Bizim Türk insanının her şeyi lafta. 3 belediye var mesela Karesi, Altı- 
eylül, Büyükşehir. Neden toplanma bölgeleri yok, niye yapılmıyor. Valilik şu anda şehrin mülkü amiri. Vali Bey her yere emir verebilir. Vali Bey yapin dese yapulır ama bir yeri eksik kalıyor. Ya tam hale getir şunu, yerleri belli olsun. (erkek, 67 yaşında, 22 yıllık muhtar)

Görüldügü üzere muhtemel bir afet durumunda hangi kurum/ kuruluşların kendilerine daha iyi hizmet sunacağı ve hangisine daha fazla güvenecekleri hususunda muhtarlar arasında belli bir çeşitlilik vardır. Çoğunluk bu hususta belediyelere daha fazla güvenirken bazıları Valiliğe daha fazla güvenmekte, azınlık sayılabilecek bazı muhtarlar da her iki kuruma da pek güvenmemektedir. STK'lara güven ise hemen hemen hiçbir muhtarın ifade etmediği bir husustur.

\section{Belediyeler ve STK'lara Bakışları}

5393 sayılı Belediye Kanunu'nun 41. maddesinde Belediye Başkanının hazırlaması gereken Stratejik Plan hakkında; “... varsa üniversiteler ve meslek odalarn ile konuyla ilgili sivil toplum örgütlerinin görüşleri alınarak hazırlanır ve belediye meclisi tarafindan kabul edildikten sonra yürürlü̈̆e girer" hükmüne yer verilmiştir. Bu da yerel yönetimlerin gerek STK'lar / gönüllü kuruluşlar, gerekse diğer kamu kurum ve kuruluşlarıyla işbirliği içinde bulunarak hareket etmeleri gerektiğini göstermektedir.

$\mathrm{Bu}$ doğrultuda, muhtarlara sorulduğu gibi, belediye yöneticilerine de afet konusunda sivil toplum ve gönüllü kuruluşlarla irtibat ve çalışma durumlarının ne durumda olduğu soruldu. Böylece belediyelerin STK'larla işbirliğine nasıl baktıklarını anlamayı amaçladık. Belediyelerin tamamı genel olarak sivil toplum ve gönüllü kuruluşlarla birtakım irtibat ve çalışmalarının bulunduğunu belirtmiştir:

İşbirliği yaptığımız sivil toplum örgütleri var ama doğal afet konusunda işbirliği yaptı̆̆ımız herhangi bir sivil toplum örgütü yok. Tabii Kızılay Türkiye'nin çok önemli bir birimi, önemli bir örgütü. Gerçekten Türkiye için çok büyük bir kazanç. ... Şimdi burada doğal afetin cinsine göre bu sivil toplum örgütleri de farklllk oluşturabilir. Kızılay doğal afetten sonra bu konuda aktif çalışan bir birim. Ama mesela doğal afetin cinsine göre de, örnek veriyorum deprem açısın- 
dan bakacak olursak jeoloji mühendisleri odası, inşaat mühendisleri odası, meslek odalarının da bu konuda aktif çalışması gerekiyor.

Bununla beraber bazı belediye yöneticileri Balıkesir ilindeki STK'ların pek aktif olmadığını şu sözlerle vurgulamaktadır:

Balıkesir'de sivil toplum kuruluşu çok yok. Bu konuda arama kurtarma derneği veya diğer konularda yaklaşık 4-5 tane kadar dernek var. Bunlarla genelde eğitim anlamında çalışıyoruz. Zaten onlar da genelde AFAD'ın sistemine entegre olmak zorunda, çünkü öyle bir durum olduğu zaman herkes kendi bildiğine olay bölgesinde fiilen bulunamıyor. Artık AFAD sistemi üzerinden ihtiyaç varsa ihtiyaç olan bölgenin kontrolüne göre yönlendiriliyorsunuz, ama bizim buradaki açı söyleyeyim sivil toplum kuruluşları çok da aktif değiller.

Belediyelerin afet hazırbulunuşluğu sürecinde STK'larla işbirliği yapma hususunda birbirlerinden farklılaştıklarını gözlemlemek de mümkün. Bazıları buna daha sıcak bakarken bazıları daha mesafeli durmaktadırlar. Örneğin belediye yöneticilerinden biri özellikle afet farkındalık yaratma çalışmalarının genelde STK'lar tarafından yapılması gerektiğini şu şekilde ifade etmiştir:

Biraz da bu sivil toplum kuruluşlarmnn vermesi gereken bir iş, bizim kent konseyimiz var oldukça faal. O kent konseyinde bu konu gündemde bizim. Okullarda bu tür çalışmalar yapmak için, şu anda üzerinde çalışılıyor. Bakalım, ilerleyen günlerde şekillenecek. ... Bütün siyaset üstü, sivil toplum kuruluşlarının da içinde bulunması gereken bir konu. Onların verdiği görevlerle beraber belediyemiz de bu konuda görevini alacaktır.

Öte yandan afet yönetimi süreçlerinde STK'larla işbirliği yapmaya mesafeli bakan bir belediye yöneticisi bu süreçlerin çok başlı olmaması gerektiğini savunmaktadır:

Soru: Afet hazırbulunuşluğu süreçlerinde işbirliği yaptığınız STK'lar var mi?

- Hayır, Yok.

Soru: Sadece Kizılay var yani? 
- Zaten bir tane olsun, yeter. Zaten çok başlı olmaz ki bu işler. AFAD'ımız var, Kizllay'ımız var, yeter.

Nicel araştırma bulgularımız hanehalklarının da gerek doğru bilgi gerekse yardım alma hususlarında STK'lara pek güvenmediğini ortaya koymuştu. Yukarıdaki alıntı en azından bazı belediye yöneticilerinin de STK'lara karşı güvensiz ve kuşkucu bir bakış açısı taşıdıklarını göstermektedir.

Belediyelerin STK'larla işbirliği ve güven durumlarına ilave olarak muhtarlarla işbirliğine nasıl baktıkları da araştırma için önemlidir. Muhtarlar hem yerel topluluk üyeleriyle hem yerel yönetim liderleriyle yakın irtibat halinde ve bu ikisi arasında aracılık yapabilen, mahallelerinin coğrafi, sosyal, demografik ve kültürel özelliklerini iyi bilen, afet yönetim süreçlerine görüş ve önerileriyle ortak edilmesi gereken aktörlerdir. Acaba belediyeler bu hususu dikkate almakta ve muhtarlarla aktif işbirliği yapmakta mıdırlar? Bunu anlamaya yönelik sorularımıza verilen yanıtlar muhtarların bu sürece edilgen aktörler olarak dâhil edildiklerini göstermektedir. Buna işaret eden birkaç açıklama şu şekildedir:

Muhtarlarla sürekli toplanma halindeyiz. Toplantılar yapilyyor herhalde 8 tane yapıld, her konuda olduğu gibi. Yani kursal mahallelerindeki önerileri, sorunlarn ile ilgili her türlü mevzuda, afet durumunda da kime ulaşacaklar, acil durumda ne yapacaklarn ile ilgili toplantılarda bilgiler aktarllyor, seminerler veriliyor, hatta tüm başkan yardımcılarımızın telefon numaraları veriliyor acil durumlarda iletişim kurmaları için. Sürece hepsini dâhil ediyoruz, dediğim gibi sadece doğal afet konusunda değil, diğger her türlü konuda da STK, üniversite, muhtar hepsiyle kontak halindeyiz.

Belki yeteri kadar değil denilebilir ama hiç de denilemez yani. Biraz daha bu katılımı iyileştirmek gerekebilir. Yani katılımı, çağrıyı, bilgilendirmeyi ama bu da biraz arz-talep meselesi. Bu tür konular insanlara hayati önem taşımasına ră̆men sıkıcı geliyor. Çağırıyorsun, hayati önem taşıyor, geleceği kurtaracak, belki bir 10 saniyelik zamanda bütün hayatın kurtaracak. Ama çok bilinçli bir toplum yok yani onu söyleyeyim. 
Daha önce afet farkındalık çalışmalarına toplumun ilgisizliğinden söz eden bir belediye yöneticisinin karamsar yaklaşımında olduğu gibi yukarıdaki alıntı da muhtarların ilgisizliğinden şikâyetçi olma eğilimindedir. Ancak muhtarlar da kendilerinin dâhil edildikleri faaliyetlerde kendilerine pasif roller verilmesinden şikâyetçi görünmektedirler. Nitekim bir muhtar şu çarpıcı tespitte bulunmuştu:

Biz şimdiye kadar çok toplantıya, seminere, eğitime çağrıldık. Ama bize düşen rol sadece konuşmacıları dinlemek ve onları alkışlamaktı. Illk defa bu çalıştayda bizim de görüşlerimiz sorulmakta ve bize konuşma, kendimizi ifade imkânı verilmekte. Bunun için size çok teşekkür ediyorum. Eğer bu çalıştayınıza davet ettiğiniz muhtarlar içerisinde gelmeyenler varsa bunun sebebi yine önceki toplantılarda, seminerlerde, eğitimlerde olduğu gibi kendilerine düşen rolün alkışlayıcı olacă̆ını zannetmelerinden dolayıdır.

Dolayısıyla, gerek belediyelerin gerek diğer kurumların muhtarlar (ya da başka aktörlerle) herhangi bir ortak eylem yapacakları zaman onları gerçek anlamda sürecin katılımcıları kılmaları önem taşımaktadır. Öte yandan bir başka belediye yöneticisi kendilerinin de zaten paydaşlardan sadece birisi olduklarını, asıl koordinatör aktörün AFAD olduğunu şu şekilde açıklamaktadır:

Sistemi zaten AFAD yönettiği için AFAD dâhil ediyor, bizim dâhil ettiğimiz herhangi birileri yok. Biz hep paydaşız, katılımoı paydaş yani.

Afetle birlikte mümkün olan en kısa süre içerisinde çok sayıda insan hayatını kurtarma, yaralıların tedavisini sağlama, açıkta kalanların, barınma, beslenme, tahliye, korunma, ısınma, güvenlik, psikolojik destek gibi hayati gereksinimlerini karşılanması gerekmektedir. Bu müdahale evresinde devletin gerekli tüm güç ve kaynaklarının en hızlı ve etkili yöntemlerle afet bölgesine sevk edilmesi ve çok iyi bir koordinasyonun sağlanması gerektirmektedir. Bu bağlamda hanehalklarının ve muhtarların en çok hangi kurumlara güvendiğini, özellikle belediyelerden beklentilerin çok yüksek olduğunu önceki bölümlerde görmüştük. Acaba belediyeler kendilerini bu bağlamda nerede görmektedir? Bunu anlamak 
için "muhtemel bir afet durumunda, Balıkesir halkına en çok hangi kurum ve kuruluşların destek ve yardım faaliyetleri sağlayacağını düşünüyorsunuz" sorusu yöneltildi. Belediye yöneticilerinin çoğu, vatandaşlara ilk olarak bu yardım ve desteği il/ilçe belediyelerinin sunacağını belirtmişlerdir. Her ne kadar afete müdahale ve koordinasyon sorumluluğu Valilik/AFAD üzerinde olsa da belediye yöneticileri kendi kapasitelerini AFAD'ın kapasitesi ile karşılaştırma yaparak vurgulama gereği duymaktadırlar. Aşağıdaki iki alıntı bunu açıça sergilemektedir:

Şimdi AFAD'ın kabiliyet alanının refleks alanmmn belediye kadar geniş olduğunu düşünmüyorum. Öyle bir afet durumunda ilk aranan yer belediye olur. Illk başvurulan yer belediye olur. Çünkü belediyenin yönetimsel, siyasi veya idari yönetimleri halkın içine dağılmış haldeler. Mutlaka en yakın şekilde en hızlı bu süreçte destek ve yardım sunan belediye olur diye düşünüyorum.

Gayet net Balıkesir Büyükşehir Belediyesi, direk çok net konuşuyorum. Balıkesir'de 4-5 tane sel felaketi oldu, toprak kayması oldu, maden kazası oldu birkaç tane. Hepsinde niye büyükşehir belediyesi, çünkü AFAD sadece organizasyon kısmında. Yani sayısal olarak konuşmak gerekirse şimdi bugün burada İl AFAD müdürlüğünde bir noktada 28 tane personel var. Benim İtfaiye Daire Başkanlığ olarak 35 noktada 650 personelim var. Araç ve ekipman olarak AFAD'ın il genelinde şu anda 4 tane kurtarma aracı var. Benim il genelinde 190 tane aracım var. Yayginlık olarak da aynı şekilde. Yaygınlıktan kasit araçsal olarak da değil, bende bölgeyi bilen insanlar çalışıyor. Yani Dursunbey'de Dursunbey'i bilen adam çalışıyor. İvrindi'de Ivorindi'yi bilen adam çalışıyor. Bizim avantajımız şu; araç birliği, ekipman birliği olduğu için. Ben burada şimdi atıyorum Altınova'da sel felaketi oldu, ben mesela Bandırma'daki Erdek'teki ekipleri oraya kaydırdım. Hiçbir aksama olmadı niye, ayn ekipman, personel amirler aynı en üst personel ayni. ekstrem ikinci durum atıyorum sel baskın diyelim büyük bir sel baskın. su ve kanalizasyonla ilgilenen bir birimle muhatap olman lazım. Bunu da zaten BASKI Büyükşehir Belediyesi. Kaymakamlıkta yok, Valilikte AFAD'da yok. Ben onlarla koordinasyonu daha iyi sağlıyorum niye çünkü benim yan kuruluşum. Şimdi ben sadece telefondan ve telsizden talimat ve- 
riyorum arkadaşlar diyorum Gömeçte sıkıntı var, Ayvalık, Edremit, Burhaniye sıklaşıyorsunuz, Balıkesir Merkez'den de onlarm boşalttıkları yerlere hemen ekip kaydırıyorum. Sürekli böyle bir hareket halinde oluyor. Böyle olunca 2-3 dakika içinde karar vermem lazım dakikalarla oynanıyor. En önemlisi kamu güvenliği biz bunun için varı. Adamın başına bir şey geldiğinde adam bilmeli benim gelip kurtaracağımın rahatlı̆̆ içinde olmalı. Elimdeki sistemden de araçlarn ekipleri takip edebiliyorum. Bu konuda sürekli olan kişi benim; benden başka alternatif yok. Bu sistemi ben görüyorum şimdi sistem 112, bunu ben görüyorum, İtfaiye, Emniyet, Valilik hepsini takip edebiliyor. Kurtarma ve güç gerektiren işleri Büyü̈şshir Belediye yapmakta diğer kurumlar sadece koordinasyon başka bir şey değil.

Bazı belediye yöneticileri de belediye ve AFAD'ın (devlet kurumlarının) kapasitesi ile STK'ların kapasite ve etki güçlerini karşılaştırma gereği duymakta ve afet durumunda Balıkesir halkına en çok Valilik kapsamında AFAD'ın ve belediyenin destek ve yardım sunacağını düşünmektedirler. Örneğin bir belediye yöneticisi bu görüşü şu sözlerle yansıtmaktadır:

Bence şöyle, Valiliğin çatısı altında AFAD ve belediyeler sunar en çok yardımı. AFAD'ın yerleri var ekipmanları var, belediyelerin de aynı şekilde. Tabi STK'ların da desteğini azımsamamak lazım ama şimdi şöyle düşünün bir özel hastanede çalışan doktor sayısı 20 tane, devlet hastanesinde 200 tane. Neden çünkü karşılama kapasitesi var. Mesela, STK'nın üyesi vardır 30 tane, manevi destek olur ama maddi nasıl olsun. O da başkasindan destek alıyor. Ama yerelde genelde Valilik AFAD koordinasyonunda belediyeler hem maddi olarak hem araç olarak her türlü en büyük desteği sağlar. Ama tabi sadece STK'lar değil, parti kolları, gençlik kolları da zaten insan gücü olarak manevi olarak işte gerekse ellerindeki maddi destek kadarıyla da böyle durumlar yardım sağlıyorlar.

\section{AFAD ve STK'lara Bakışları}

Afet ve Acil Durum Yönetimi Başkanlığı (AFAD), resmi web sitesinde, kendilerinin afet ve acil durumlara ilişkin tek yetkili kurum olduklarını, bir şemsiye kurum anlayışıyla afet ve acil durumun niteliği ve büyüklüğüne göre gerek Genelkurmay Başkanlığı, D1- 
şişleri, Sağlık, Orman ve Su İşleri ve ilgili diğer bakanlıklar ile gerekse sivil toplum kuruluşları ile işbirliği içerisinde faaliyetlerini sürdürdüklerini bildirmektedir ${ }^{1}$.

$\mathrm{Bu}$ resmi bilgiden hareketle AFAD yetkililerinden diğer resmi kurumlarla ve STK/gönüllü kuruluşlarla afet konusunda yapmış oldukları çalışmalar ve irtibat durumları hakkında bilgiler vermeleri istenmiştir. Bu bağlamda şu şekilde açıklama yapılmıştır:

Bandırma Üniversitesiyle var, diğer kurumlarla protokollerimiz var bu hizmet kurumlarıla. Zaten Kizllay da bu 26 hizmet grubuna dâhil bu diğer sivil toplum kuruluşlarını da dâhil ettik bu protokole. Kızılay'dan başka kuruluş olarak STK'lar var, Ayvalık Doğal Afet kurtarma ekibi, Gönen Doğal afet kurtarma ekibi, Bandırma'da var, Balıkesir'de de Balıkesir Arama Kurtarma (BAK) diye bir ekip var. Bunlardan da yer yer arazide destek aldığımız oluyor.

Yukarıdaki ifadeye göre, AFAD'ın hem üniversite ile hem de diğer resmi kurumlar ve STK'lar ile işbirliği içinde olduğu, Türkiye Afet Planı dâhilindeki 26 hizmet grubuna bu kurum ve kuruluşların dâhil olduğu görülmektedir.

Çalışmada Valilik-AFAD birimine, afet durumunda Balıkesir halkına en çok yardım ve desteği sağlayacak kurum/kuruluş olarak kendilerini ve diğer aktörleri nerede konumlandırdıkları da sorulmuştur. Bu kapsamda AFAD yöneticileri kendi kurumlarının en önemli ve etkin aktör olduğunu şöyle ifade etmişlerdir:

Belediyeler, kısmen tabi ki destek olacaktır, yani muhakkak ihtiyaç da olacaktır. Sivil toplum kuruluşları da destek sağlayabilirler çünkü gönüllü oldukları için, ekipleri olanlar da var, bütün donanımı olanlar da var kesinlikle faydası olacaktır ve zaten de desteklenmeliler. Ancak AFAD en büyük desteği verir çünkü bütün organizasyonu biz yapacă̆ımız için suyun kaynağı burası olacaktır. Biz organize etmeden zaten hiçbir şey yapılamaz.

AFAD yetkililerinin yaptığı bu tür açıklamalar araştırmacının bir

1 https://www.afad.gov.tr/tr/2211/AFAD-Hakkinda (Erişim: 25 Kasım 2017). 
tatbikat sırasındaki gözlemleriyle de desteklenmiştir. Nitekim bu tatbikatta AFAD, 24-25 Eylül 2019 tarihlerinde kendi personeli, 26 yerel düzey hizmet grubu ve STK temsilcilerinden oluşan toplam 307 kişinin katılımlarıyla masabaşı ve saha tatbikatlarını eşzamanlı olarak gerçekleştirmiştir. Her iki tatbikatta da 12 STK ile etkili bir işbirliği yapıldığı gözlenmiştir.

\section{Sonuç ve Tartışma}

Araştırmanın bütününden elde edilen ana bulgular şu şekilde özetlenebilir:

- Güven duyulan aktörler bağlamında Balıkesir'de hanehalklarının çok büyük bir kısmı (\%80'den fazlası) olası afetlerde tüm ilgili devlet kuruluşlarının (özellikle belediyelerin ve AFAD'ın) ve Kızılay'ın kendilerine doğru bilgi vereceklerine ve yeterli yardım ve desteği sunacağına güvenmektedirler. Bilgi kaynağı olarak hanehalklarının yerel medyaya güvenleri (\%56), ulusal medyaya güvenlerinden (\%65) daha azdır. Hanehalklarının bilgi kaynağı olarak sivil toplum kuruluşlarına güvenleri de (\%56), yardım kaynağı olarak güvenleri de (\%66) devlet kuruluşlarına ve Kızılay'a güvenin çok altında kalmaktadır. Sivil toplumun unsurları kapsaminda değerlendirilebilecek bir başka aktör olan dini cemaatlere güven ise (\%33) oldukça düşük seviyededir.

- Afet yönetişimi bağlamında mahalle muhtarları ile sivil toplum kuruluşları arasında etkili ve önemli bir işbirliği bulunmamaktadır. Ayrıca mahalle muhtarlarının çoğu, destek veya yardım sağlayacak kurum/kuruluş olarak sivil toplum kuruluşlarına pek güven duymamaktadırlar. Bunun yerine muhtarlar, afet durumunda en çok belediyelerin kendilerine yardım ve destek sunacağını düşünmektedirler.

- Belediye yöneticileri doğal afet gibi olağanüstü durumlar için Türk/Balıkesir halkının özverili tutum ve davranışlarına yüksek oranda güvenmektedirler. Belediye yöneticilerinin bu tutumu onların afet-sonrası müdahaleye odaklandıklarının ve afet-öncesi hazırbulunuşluğu önemsemediklerinin bir göstergesidir. Belediye yöneticilerinin yaklaşımlarına göre 
hâlihazırda herhangi bir hazırlığımız olmasa da bir afet sırasinda herkes üstüne düşeni yapar.

- Belediyelerin tamamı sivil toplum ve gönüllü kuruluşlarla birtakım irtibat ve çalışmalarının bulunduğunu belirtmekte ama Balıkesir ilindeki STK'ların pek aktif olmadığını düşünmektedirler. Bazıları STK'larla işbirliğine daha sıcak bakarken bazıları daha mesafeli durmaktadırlar. Belediyeler afet yönetim süreçlerinde muhtarlarla yakın ilişki içindedirler ama onlara genellikle edilgen roller vermektedirler. Bazı belediyeler muhtarların ilgisizliğinden şikâyetçidir.

- Belediye yöneticilerinin çoğu, muhtemel bir afet durumunda vatandaşlara yardım ve desteği ilk olarak il/ilçe belediyelerinin sunacağını belirtmişlerdir. Her ne kadar afete müdahale ve koordinasyon sorumluluğu Valilik/AFAD üzerinde olsa da belediye yöneticileri kendi kapasitelerini AFAD'ın kapasitesi ile karşılaştırma yaparak öne çıarma gereği duymaktadirlar.

- $\mathrm{AFAD}^{\prime}$ in hem üniversite ile hem de diğer resmi kurumlar ve STK'lar ile işbirliği içinde olduğu, Türkiye Afet Müdahale Planı dâhilindeki 26 hizmet grubuna bu kurum ve kuruluşların dâhil olduğu belirtilmiştir. AFAD yetkilileri, afet durumunda Balıkesir halkına en çok yardım ve desteği sağlayacak kurum/kuruluşun kendileri olduğunu düşünmektedirler. AFAD yetkililerinin "biz organize etmeden zaten hiçbir şey yapılamaz" sözü dikkat çekicidir.

Yukarıdaki bulguların tüm Türkiye için genellenebilirliğinden söz edilemez. Özellikle İstanbul, Ankara, İzmir gibi mega kentlerde ve diğer bazı bölgelerde bu araştırmanın sunduğundan daha farklı bulgular elde edilebilir. Ancak Balıkesir özelinde elde edilen bu bulguların Türkiye'nin birçok bölgesi için de geçerli olabileceği varsayılmaktadır.

Yukarıdaki bulgular, Türkiye' de afet yönetişimiyle ilgili literatürde baskın paradigma olarak beliren "güçlü devlet/ zayıf sivil toplum" paradigmasının temel varsayımlarına karşı önemli ölçüde aykırılıklar göstermektedir. Yaygın kabulün aksine sivil topluma 
güven genel olarak devlet kurumlarına güvenin oldukça gerisindedir. Afet yönetişiminde aktif rol alması beklenen aktörler arasında etkili bir iletişim ve işbirliği hususunda hala ciddi sorunlar bulunmaktadır ancak bu sorunlar tamamen merkezi devlete hamledilemez. Afet yönetişiminde merkezi devletin sözcüsü konumundaki AFAD, yönetişim ilkelerine nispeten daha açı bir tutum sergilemektedir. Yerel yönetimlerin yönetişim ilkelerine açıklığı ise AFAD'a kıyasla daha sınırlı görünmektedir. Buna rağmen yerel yönetimler bağlamında belediyeler toplumsal tabanın güvenini kazanma hususunda akraba, arkadaş ve komşulardan sonra diğer tüm aktörlerden daha fazla başarı sergilemektedirler.

Türkiye'de 1999 Marmara depremleriyle beraber ilgi ve etkinlik kazandıkları düşünülen STK'ların afet yönetişimindeki mevcut durumu bir "geri çekilme" olarak görülebileceği (Gümüş, 2004:3) gibi bir güven kırılması olarak da yorumlanabilir. Birçok STK'nın 2013 yılındaki Gezi Parkı olaylarına ve genel olarak PKK merkezli ayrılıkçı hareketlere açık ya da örtük destek verdiğinin anlaşılmasından ve afete müdahale de dâhil birçok alanda faaliyetler yürüten STK'larla ilişkisi bilinen FETÖ'nün 15 Temmuz 2016 tarihindeki darbe kalkışmasından sonra devlet kurumları kadar toplumun da STK'lara karşı alarm durumuna geçtiği ve STK'lara karşı genel bir güvensizliğin güçlendiği söylenebilir. Diğer bir deyişle, Türkiye'de STK'lar kolayca siyasallaşmakta, topluma hizmetten ziyade siyasal sisteme müdahale araçlarına dönüşebilmektedir. Bunun yanı sıra Türkiye' de STK'ların şeffaflık, istismar, yozlaşma gibi yapısal sorunları da mevcuttur. Elbette bunları bütün STK'lara genellemek büyük bir yanlıştır. Bugün itibariyle devlet de toplum da böyle bir genellemeden uzak durmakla beraber STK'lara karşı seçici ve tedbirli bir tutum sergilemeyi tercih etmektedir. Bu durumu "sivil toplumdan korkma" olarak değerlendirmek yerine, özellikle 11/2001'den beri bütün dünyada etkili olduğu gibi Türkiye'de de güvenlik kaygılarının devlet-sivil toplum ilişkilerini yeniden düzenlediğini düşünmek daha isabetli olacaktır.

Elbette sivil toplumun afet yönetişimine sunabileceği pozitif katkıları güvenlik kaygılarına kurban etmek “banyo suyuyla beraber 
bebeği de atmak" anlamına gelecektir. Bunun önüne geçmek için yerel yönetimlerin de merkezi devlet kurumlarının da kendini kanıtlamış, siyaset üstü STK'larla daha fazla iletişim ve işbirliği geliştirmesi, afet yönetiminde rol almak ve katkı sunmak isteyen STK'ların da güven tazelemesi gerekli görülmektedir.

\section{Teşekkür}

Yazar, bu makaleye kaynaklık eden “Balıkesir'de Aile, Yerel Yönetimler ve Doğal Afetler: Farkındalık, Hazırlık, Güven ve Sosyal Sermaye Açılarından Sosyolojik Bir İnceleme" başlıklı ve 116K208 numaralı projeyi desteklediği için TÜBİTAK'a, projede rol alan araştırmacılar, Alper Uzun, Abdurrahman Özkan ve Barış Şentuna'ya, bursiyer Ali Egi'ye ve katkı sunan tüm öğrenci ve dostlara teşekkür eder. 


\section{Kaynakça}

Akgüngör, Ç. (2010). “Toplumbilim Perspektifinden Afeti Düşünmek" LAÜ Sosyal Bilimler Dergisi, 1:1, Ss.3-22.

Alexander, D. (2005). "An Interpretation of Disaster in Terms of Changes in Culture, Society and International Relations", iç. Ronald W. Perry, E.L. Quarantelli (Eds), What Is A Disaster? New Answers To Old Questions, USA.

Ammann, W. J., Dannenmann, S. \& Vulliet, L. ed. (2006). RISK21 Coping with Risks due to Natural Hazards in the 21st Century: Proceedings of the RISK21 Workshop, Monte Verità, Ascona, Switzerland, 28 November - 3 December 2004. London: CRC Press.

Aydıner, T. ve Özgür, H. 2014. "Yönetişim ve Doğal Afetler: Türkiye' de Doğal Afet Yönetişimi Ne Kadar ve Hangi Biçimde Mümkün?", iç. Kamu Yönetiminde Değişim Kayfor XII Bildiriler Kitabı, Fatma Neval Genç (Ed.) ISBN: 978-975-8254-538.

Bayraktar, N. ve Dalyılmaz, N. (2018). “Vulnerability of Elderly People in Disasters: A Systematic Review", Turkish Journal of Geriatrics DOI: 10.31086/tigeri.2018344062. 2018; 21(3):467-482.

Beratan, K. K. (2007). A cognition-based view of decision processes in complex social-ecological systems. Ecology and Society, 12(1), 27.

Bodstein, A. ve Barros, A. M. A.(2014). "The vulnerability of the elderly in disasters: The need for an effective resilience policy," Ambiente \& sociedade 17(2):157-174.

Coleman, J. S. (1988). "Social Capital in the Creation of Human Capital." American Journal of Sociology, 94: 95-120.

Dahiya, B. (2012). "Cities in Asia, 2012: Demographics, economics, poverty, environment and governance." Cities 29: S44-S61. doi: 10.1016/j.cities.2012.06.013.

Dynes, R. R. (2002). "The Importance of Social Capital in Disaster Response" University of Delaware Disaster Research Center, Preliminary Paper \#327.

Edwards, M. (2004). Civil Society, Cambridge: Polity.

Enarson E. (2012). Women Confronting Natural Disaster: from Vulnerability to Resilience. Lynne Rienner Publ. US. 
Fukuyama, F. (1995). Trust: The Social Virtues and the Creation of Prosperity. London: Hamish Hamilton.

Gall, M., Cutter, S. L. \& Nguyen, K. (2014). Governance in Disaster Risk Management (IRDR AIRDR Publication No. 3). Beijing: Integrated Research on Disaster Risk.

Ganapati, N. E. (2005). "Rising From The Rubble: Disaster Victims, Social Capital, And Public Policy - Case of Golcuk, Turkey", A Dissertation Presented to the Faculty of The School of Policy, Planning, and Development, University of Southern California.

GIVE2ASIA \& IIRR. (2017). Building Community Resilience: Mapping the Journey of Local Community based NGOs in Developing Sustainable Preparedness Programs. White Paper, Spring 2017.

Gümüş, K. (2004). "Yakın Tarihimizde STK hareketinin gelişimi ve Kamu Sivil Toplum Kuruluşları İlişkisi". Savunuculuk ve Politikaları Etkileme Konferans Yazıları, No: 3, 1-35.

GYODER. (2015). Balıkesir İli Yatırım Alanları Vizyon Raporu Değerlendirme ve Öngörüler https: / / www.gyoder.org.tr/uploads / Yay\%C4\%B1nlar/arastirma_raporlari/ar4.pdf (Erişim: 8 Mayıs 2018).

Hartog, J. (2014). Disaster Resilience in an Ageing World: How to Make Policies and Programmes Inclusive of Older People. HelpAge International. https: / / www.unisdr.org/2014/iddr/ documents / DisasterResilienceAgeingWorld.pdf

Hermansson, H. (2016). “Disaster Response in Turkey: Conditions Promoting Cross-Sectoral Collaboration and Implications for Effectiveness." Administration \& Society, 51(7): 1051-1078.

Hilhorst, D. J. M. (2007). The art of NGO-ing: Everyday practices as key to understanding development NGOs. In P. OpokuMensah, D. Lewis, \& T. Tvedt (Eds.), Reconceptualising NGOs and their roles in development (297-325). Aalborg, Denmark: Aalborg University Press.

Hogg, M. (2007). Social identity and the group context of trust: managing risk and building trust through belonging. In Siegrist, M., Earle, T.C., Gutscher, H. (Eds.), Trust in Risk Management. Earthscan: London. 
Ile, I. (2009). Managing Intergovernmental Relations: A case review of intergovernmental relations systems in Nigeria and South Africa. Saarbrucken:VDM Verlag Dr. Muller Aktiengesellschaft \& Co. KG.

Inglehart, R. (1990). Culture Shift in Advanced Industrial Society, Princeton University Press, Princeton.

Inglehart, R. (2001). Trust, Social Capital, Civil Society, and Democracy, International Political Science Review, 22: 201-214.

Jalali, R. (2002). 'Civil Society and the State: Turkey after the Earthquake', Disasters, 26(2): 120-139.

Janssen, M., Lee, J., Bahrosa, N., Cresswell, A. (2010). Advances in multi-agency disaster management: key elements in disaster research. Information Systems Frontiers, 12, 1-7.

Kahan, D.M., Jenkins Smith, H., Braman, D. (2011). Cultural cognition of scientific consensus. Journal of Risk Research, 14, 147-174.

Kahn, M. E. (2005). “The Death Toll from Natural Disasters: The Role of Income, Geography, and Institutions", Review of Economics and Statistics, 87(2): 271-284. doi:http://dx.doi. org / 10.1162/0034653053970339

Kapucu, N. (2005). Interorganizational coordination in dynamic context: networks in emergency response management. Connections, 26, 35-50.

Kapucu, N., Garayev, V. (2011). Collaborative Decision-Making in Emergency and Disaster Management, International Journal of Public Administration, 34 (6), 366-375.

Kent, R., Armstrong, J., \& Obrecht, A. (2013). The future of nongovernmental organisations in the humanitarian sector: Global transformations and their consequences. Humanitarian Futures Programme Discussion Paper for the Start Network, Kings College, London, UK.

Kieger, K. (2013). "The limits and variety of risk-based governance: The case of flood management in Germany and England." Regulation \& Governance 7 (2): 236-257.

Kubicek, P. (2002). “The Earthquake, Civil Society, and Political Change in Turkey: Assessment and Comparison with Eastern Europe", Political Studies, Vol. 50, 761-778. 
Lassa, J. A. (2018). "Roles of Non-Government Organizations in Disaster Risk Reduction" Oxford Research Encyclopedia of $\mathrm{Na}$ tural Hazard Science, Online Publication Date: Jun 2018 DOI: 10.1093/acrefore/9780199389407.013.45

Longstaff, P. H., Yang, S. (2008). Communication management and trust: their role in building resilience to "surprises" such as natural disasters, pandemic flu, and terrorism. Ecology and Society, 13(1): 3 .

Luhmann, N. (1988). "Familiarity, Confidence, Trust: Problems and Alternatives." In Trust: Making and Breaking Cooperative Relations (D. Gambetta, ed.), 95-107. Oxford: Blackwell.

Luna, E. (2001). 'Disaster Mitigation and Preparedness: The Case of NGOs in the Philippines', Disasters, 25(3): 216-226.

Maskrey, A. (1989). Disaster mitigation: A community based approach. Oxford, UK: Oxfam.

Moe, T., L., Pathranarakul, P. (2006). An integrated approach to natural disaster management: Public project management and its critical success factors, Disaster Prevention and Management, 15 (3), 396-413.

Nick, G.A., Savoia, E., Elqura, L., Crowther, S., Cohen, B., Leary, M., Wright, T., Auerbach, J. Kohn, H. K. (2009). “Emergency Preparedness for Vulnerable Populations: People with Special Health-care Needs" Public Health Rep. 2009, 124(2): 338343. doi: $10.1177 / 003335490912400225$.

Odabaş, Z. Y. (2010). Sürdürülebilir Afet Yönetimi ve Kadın. Ankara Üniversitesi Rektörlüğü Yayınları: 256, Ankara.

Odabaş, Z. Y. (tarihsiz). Depremin Sosyolojik Incelenmesi: 2011 Van Depremi, Atatürk Üniversite Bilimsel Araştırmalar Projesi Sonuç Raporu. https:/ / docplayer.biz.tr/48524032-Depreminsosyolojik-incelenmesi-2011-van-depremi.html (son erişim: 03 Ocak 2010).

Osa, Y. (2013). "Growing Role of NGOs in Disaster Relief and Humanitarian Assistance in East Asia" in A Growing Force: Civil Society's Role in Asian Regional Security, edited by Rizal Sukma and James Gannon, Japan Center for International Exchange, Washington DC. 
Özerdem, A. ve Jacoby, T. (2006). Disaster Management and Civil Society Earthquake Relief in Japan, Turkey and India. I.B.Tauris \& Co Ltd, New York.

Palttala, P., Boano, C., Lund, R., Vos, M. (2012). Communication Gaps in Disaster Management: Perceptions by Experts from Governmental and Non-Governmental Organizations. Journal of Contingencies and Crisis Management, 20, 2-12.

Peduzzi, P., Dao, H., Herold, C., ve Mouton, F. (2009). “Assessing Global Exposure And Vulnerability Towards Natural Hazards: the Disaster Risk Index," Natural Hazards and Earth System Sciences., 9, 1149-1159, doi:10.5194/nhess-9-1149-2009

Pelling, M. (2011). “Urban governance and disaster risk reduction in the Caribbean: the experiences of Oxfam GB." Environment and Urbanization 23 (2): 383-400. doi: 10.1177/ 0956247811410012.

Pincha, C. (2008). Indian Ocean Tsunami Through the Gender Lens: Insights from Tamil Nadu, India. Mumbai: Earthworm Books.

Platt, S. \& Durmaz, B. (2015). "Post-earthquake decision-making in Turkey: studies of Van and Izmir." Disaster Risk Reduction, DOI: http:/ / dx.doi.org/10.1016/j.ijdrr.2016.03.010.

Pollitt, C. (2005). “Decentralization. A Central Concept in Contemporary Public Management". İç. E. Ferlie, L. E. Lynn, Jr., \& C. Pollitt (Eds), The Oxford Handbook of Public Management (ss. 371-397). New York, NY: Oxford University Press.

Putnam, R. (1993). Making Democracy Work: Civic Traditions in Modern Italy. Princeton: Princeton University Press.

Putnam, R. (1995). "Tuning in, Tuning out: the Strange Disappearance of Social Capital in America." PS: Politics and Political Science, 28(4): 664-683.

Raschky, P. A. (2008). "Institutions and the Losses from Natural Hazards", Natural Hazards and Earth System Sciences (8), 627-634. http: / / www.nat-hazards-earth-syst-sci.net / 8 /627 / 2008 / nhess-8-627-2008.pdf (Erişim: 22 Nisan 2018).

Renn, O. (2008). Risk governance: Coping with uncertainty in a complex world. London: Earthscan.

Sandoval, V. \& Voss, M. (2016). “Disaster Governance and Vulne- 
rability: The Case of Chile", Politics and Governance (ISSN: 2183-2463), 4(4): 107-116, DOI: 10.17645/pag.v4i4.743

Sharma, A. \& Palakudiyil, T. (2003). Facing Up to the Storm - How Local Communities Can Cope with Disaster: Lessons from Orissa and Gujarat, London: Christian Aid.

Shaw, R. \& Goda, K. (2004). 'From Disaster to Sustainable Civil Society: The Kobe Experience', Disasters, 28(1): 16-40.

Simmel, G. (1950). The Sociology of Georg Simmel (K. Wolff, trans. and ed.). Glencoe, IL: The Free Press.

Stough, L. (2010). "Children with Disabilities in the Context of Disaster: A Social Vulnerability Perspective", Child Development, 81(4):1260-70.

Tarih Vakfı (2000). Sivil Toplum Kuruluşları ve Yasalar-Etik-Deprem, Türkiye Ekonomik ve Toplumsal Tarih Vakfı Yayınları, İstanbul.

Tierney, K. (2012). "Disaster Governance: Social, Political, and Economic Dimensions." Annual Review of Environment and Resources, Vol 37 37: 341-363. doi: 10.1146/annurev-environ-020911-095618.

Tyler, T. R. ve Degoey, P. (1995). Collective restraint in social dilemmas: Procedural justice and social identification effects on support for authorities. Journal of Personality and Social Psychology, 69, 482-97.

UNDP. (2001). UNDP and civil society organizations: A policy of engagement. https:/ / www.undp.org/content/dam/undp/documents / partners / civil_society / publications / 2001_UNDPand-Civil-Society-Organizations-A-Policy-of-Engagement EN.pdf (Erişim: 23 Aralık 2019).

UNDP (2010). "Disaster Risk Reduction, Governance and Mainstreaming," Bureau for Crisis Prevention and Recovry. (Oct. 2010). https:/ / www.preventionweb.net/files / 17429_4disasterriskr eductiongovernance1.pdf (Erişim: 23 Aralık 2019).

UNISDR (2005). "World Conference on Disaster Reduction, 18-2 January 2005, Kobe, Hyogo, Japan." Geneva: United Nations. UNISDR (2006). NGOs \& Disaster Risk Reduction: A Preliminary Re- 
view of Initiatives And Progress Made. Background Paper for a Consultative Meeting on A Global Network of NGOs for Community Resilience to Disasters. Geneva, 25-26 October.

UNISRD (2011). Global Assessment Report on Disaster Risk Reduction. Oxford, UK: United Nations Publications.

UNISDR (2015). Making Development Sustainable: The Future of Disaster Risk Management. Global Assessment Report on Disaster Risk Reduction. Geneva, Switzerland: United Nations Office for Disaster Risk Reduction (UNISDR).

Vasavada, T. (2013). Managing Disaster Networks in India, Public Management Review, 15 (3), 363-382.

Voss, M. (2008). “The vulnerable can't speak. An integrative vulnerability approach to disaster and climate change research." Behemoth: A Journal on Civilisation, 3(1):39-56.

Wisner, B., Blaikie, P., Cannon, T., \& Davis, I. (2004). At risk: Natural hazards, people's vulnerability, and disasters (2nd ed.). London and New York: Routledge.

YADA (Yaşama Dair Vakf1), (2014). Sivil Toplum Kuruluşlarına Yönelik Algı ve Yaklaşımlar. Türkiye' de Sivil Toplumun Gelişimi ve Sivil Toplum Kamu İşbirliğinin Güçlendirilmesi Projesi. Birinci Baskı, ISBN 978-605-83578-1-5

Yavaş, H. (2005). “Türkiye'de Doğal Afetlerin Merkez-Yerel İlişkiler Açısından Yönetim Sorunları" Dokuz Eylül Üniversitesi Sosyal Bilimler Enstitüsü Dergisi, Cilt 7; Sayı 3; S. 280-301.

Zanotti, L. (2010). Cacophonies of aid, failed state building and NGOs in Haiti: Setting the stage for disaster, envisioning the future. Third World Quarterly, 31(5), 755-771.

http:/ / www.muhtarlarkonfederasyonu.org/il-muhtarlari.html (Erişim: 10 Aralık 2019).

https://balikesir.afad.gov.tr/teskilat-semasi (Erişim: 10 Aralık 2019).

www.tuik.gov.tr (Erişim: 8 Mayıs 2018).

https: / / www.afad.gov.tr/tr/2211/AFAD-Hakkinda (Erişim: 25 Kasım 2017). 
